\title{
Dramatic global decrease in the range and reproduction rate of the European hamster Cricetus cricetus
}

\author{
Alexey Surov ${ }^{1}$, Agata Banaszek ${ }^{2}$, Pavel Bogomolov ${ }^{1}$, Natalia Feoktistova ${ }^{1}$, \\ Stefanie Monecke ${ }^{3, *}$ \\ ${ }^{1}$ Severtsov Institute of Ecology and Evolution, Russian Academy of Science, Leninsky pr. 33, Moscow, 119071, Russia \\ ${ }^{2}$ Institute of Biology, University of Białystok, Ciołkowskiego 1J, 15-245 Białystok, Poland \\ ${ }^{3}$ Institute of Chronoecology, Bismarckstr. 1, 77694 Kehl, Germany
}

\begin{abstract}
Although the European hamster is probably the fastest-declining Eurasian mammal, its IUCN Red List status is still Least Concern. In addition to the huge distribution area, this categorization is based on the assumptions (1) that the decline affects only Western Europe, where (2) modern agriculture has led to (3) an increase in the mortality of the species. Since mortality-reducing protection measures in Western Europe have been unable to stop the decline, we reviewed the literature from 1765 to the present and reappraised the situation. We found support for none of these assumptions. The species has also vanished from more than $75 \%$ of its range in Central and Eastern Europe. In 48 of 85 Russian, Belarussian, Ukrainian and Moldovan provinces, its relative occurrence has decreased. It is now rare in 42 provinces and extinct in 8. Mortality has not increased, but the reproduction rate has shrunk since 1954 throughout the distribution area. Today the reproduction rate is only $23 \%$ of that between 1914 and 1935. Taking into account the mortality of this prey species, 1 female today raises only 0.5 females for next year's reproduction. The extrapolation of the literature data points to an extinction of the species between 2020 and 2038. We strongly recommend (1) changing the status of the European hamster on the IUCN Red List from Least Concern at least to Vulnerable or even Endangered and (2) supporting scientific research on the reproduction of European hamsters as a protection measure. Global threats such as climate change, light pollution or (in the past) fur trapping are more likely to be the ultimate reason for the decline of this species than modern agriculture.
\end{abstract}

KEY WORDS: Cricetus cricetus - Distribution - Reproduction $\cdot$ Climate change $\cdot$ Light pollution $\cdot$ Global threats

${ }^{*}$ Corresponding author:

stefanie.monecke@institute-chronoecology.com

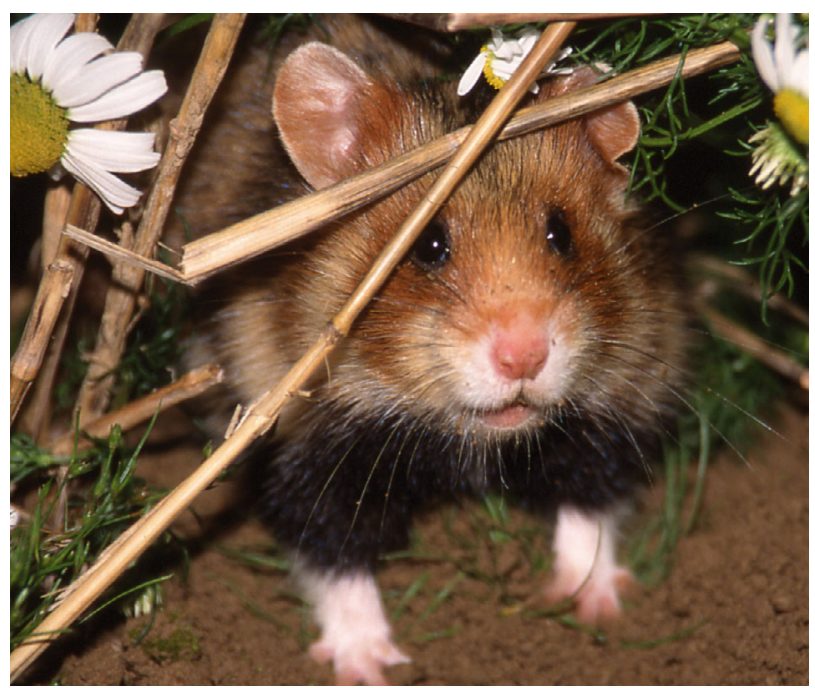

Adult female European hamster Cricetus cricetus.

Photo: Holger Fuchs

\section{INTRODUCTION}

Until the 1970s, European hamsters were a much feared agricultural pest throughout their distribution area. In 'normal' years, densities of 10 to 80 individuals per hectare were common (Ružić 1977, Nechay 2000). During pest outbreak years, which were frequent until the 1980s, population densities could increase to more than 2000 individuals per hectare as counted in Slovakia in 1971 (Grulich 1980, Nechay 2008). Thereafter, populations experienced a remarkable decline, which was first reported in Western Eu-

() The authors 2016. Open Access under Creative Commons by Attribution Licence. Use, distribution and reproduction are unrestricted. Authors and original publication must be credited. 
rope. In areas where the European hamster still exists, densities are often lower than 1 to 2 individuals per hectare (Kayser et al. 2003a, Kuiters et al. 2011). The species was included in Appendix II (strictly protected species) of the 1979 Bern Convention on the Conservation of European Wildlife and Natural Habitats, and since 1992, it has been listed in Appendix IV of the Habitats Directive, which provides strict legal protection in all European Union countries (Ziomek \& Banaszek 2007). In France, Belgium, the Netherlands and Germany, protection measures have been implemented for at least $15 \mathrm{yr}$. Since European hamsters prefer agricultural areas as habitat, farmers are compensated by 450 to $2250 €$ per year and hectare (Laussmann \& Fabry 2008, Amand et al. 2012, MKULNV 2013) for so-called hamster-friendly field management. This type of management aims to reduce mortality (Villemey et al. 2013) presumably caused by industrialized agriculture and includes small-scale cultures, restricted ploughing and late or no harvest to provide year-long food and cover for hamsters (Kayser \& Stubbe 2002, Köhler et al. 2014, La Haye et al. 2014). The French national action plan for the European hamster for 2012 to 2016 provided $4400000 €$ just for this purpose (Amand et al. 2012).

The latest census data have revealed that this hamster-friendly management has thus far not had the desired effect. In spite of protection measures, the European hamster has vanished from $75 \%$ of the Alsatian sites (France) that were still inhabited in 1997 (Amand et al. 2012, Reiners et al. 2014). In Germany, the species has been lost from one-third of the inhabited grid-squares since 1998 (compare Weidling \& Stubbe 1998 and the national Fauna-FloraHabitat Report of Germany 2013, Bundesamt für Naturschutz 2013); however, in some regions, the animal vanished from $90 \%$ of the areas (compared to 1990; Meyer 2009). Moreover, hamster densities have declined dramatically within the still-inhabited areas, for example by $90 \%$ from 250-280 animals in 2006 to ca. 25 in 2015 (D. Geiger-Roswora pers. comm.) or by $97 \%$ from 9292 active burrows in 2002 to 283 in 2011 (Mammen 2011a). Moreover, we could not find any report which indicates that hamster-friendly field management increases the numbers of European hamsters. If at all, it stabilizes the populations, but most often hamster numbers continue to decrease (Martens 2005, Mammen 2011b, Walz 2011, Weinhold 2011). Since 2001, European hamsters have been bred in captivity for reintroduction programmes to hamster-friendly areas in 3 regions (Alsace/France, Limburg/the Netherlands, Mannheim/Germany). This measure was more successful than the approach with only hamster-friendly management. In the Netherlands, population size increased (Kuiters et al. 2011), and in Germany (U. Weinhold pers. comm.) and France (Amand et al. 2012), populations could be stabilized to very low levels. However, if the number of reintroduced animals is lowered, the populations break down immediately (Kuiters et al. 2011).

The protection of the European hamster is as yet not sufficient, suggesting that the reasons for its decline are not fully understood. Moreover, the IUCN still classifies the European hamster as Least Concern (Kryštufek et al. 2008). This classification and current measures are based on 3 assumptions: (1) the decline is restricted to Western Europe, where (2) modern industrial agriculture has led to an increase in the mortality of European hamsters. Focussing on this argumentation, we reviewed literature from across the distribution area. Moreover, by reviewing historical literature from 1765 to the present, we explored other reasons for the decline, such as fecundity. We added our own data on present distribution and reproduction. Based on these results, we define properties of the potential factors impairing the survival of the species and finally discuss additional factors that merit consideration. The aim of this study is to contribute to a better understanding of the decline of the European hamster.

\section{DECLINE OF EUROPEAN HAMSTERS IS NOT RESTRICTED TO WESTERN EUROPE}

The original distribution area of European hamsters (between 42 and $55^{\circ} \mathrm{N}$ and between 5 and $95^{\circ} \mathrm{E}$; Nechay 2000) covered nearly the whole temperate zone of Eurasia and extended roughly from the Rhine River in the West to the Yenissei River in the East (Nechay et al. 1977).

In Western Europe, i.e. the Netherlands, Belgium, France, Germany and Switzerland, the decline of European hamster populations was noticed first (for a review, see Nechay 2000) (Fig. 1a,b and see Table S1 in the Supplement at www.int-res.com/articles/suppl/ n031p119_supp.pdf), and thus it was assumed that this problem concerned only the western limit of the species' distribution. However, it soon became clear that the range reduction also dramatically affected many Central European countries (Fig. 1c, Table S1). In almost all countries in which monitoring was performed recently, the species has lost large parts of its original territory so that today its range is usually fragmented (Ambros et al. 2003, Bihari 2003, Ziomek \& Banaszek 2007, Tkadlec et al. 2012). Even in East- 

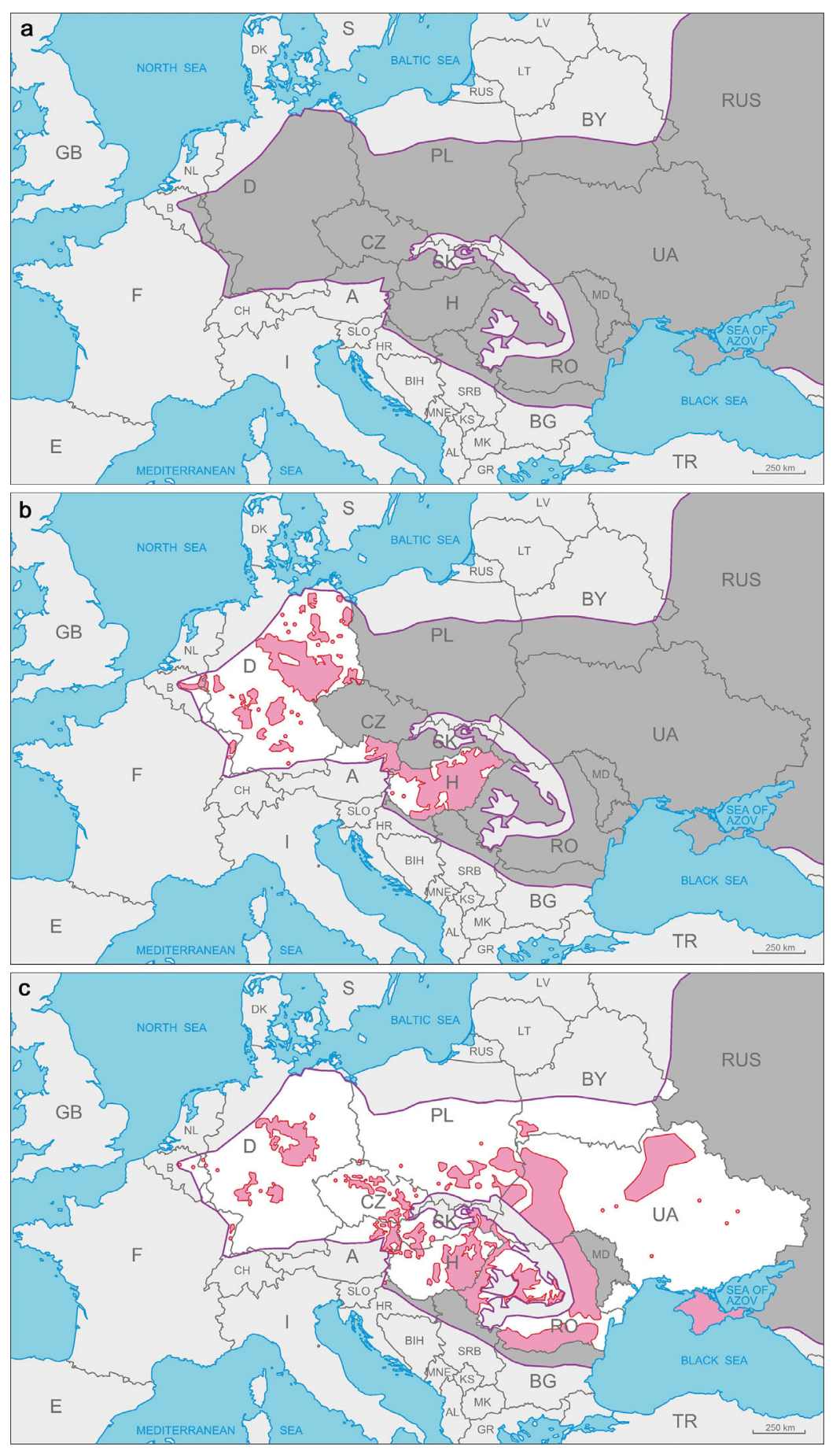

Fig. 1. Distribution of European hamsters Cricetus cricetus in Europe, excluding Russia. (a) Range before 1982 according to Niethammer (1982) (dark grey, violet borders; also applies to panels b and c). (b) Updates (Weidling \& Stubbe 1998, Nechay 2000, Weinhold 2008) as of 1998 (red) show a strong decline in hamster populations in Western Europe. (c) Current (status as of 2015) distribution in Europe according to literature given in Table S1 in the Supplement at www.int-res.com/articles/suppl/n031p119_supp.pdf, with further declines in Western Europe and remarkable declines in Central and Eastern Europe. Where no recent data are available, the distribution is left unchanged (dark grey). Further literature used to create this figure is listed in the Appendix. A: Austria, B: Belgium, BG: Bulgaria, BY: Belarus, CH: Switzerland, CZ: Czech Republic, D: Germany, F: France, HR: Croatia, H: Hungary, MD: Moldova, NL: the Netherlands, PL: Poland, RO: Romania, RUS: Russia, SK: Slovakia, SRB: Serbia, SLO: Slovenia, UA: Ukraine ern Europe, for example in Ukraine, where it was common belief that the hamster was abundant all over the country, recent studies confirmed only 3 areas of occurrence: Western Ukraine, Northeastern Ukraine and the Crimea (Korbut et al. 2013, Rusin et al. 2013). The species became extinct in most parts of the steppe zone and declined within the forest-steppe zone (Rusin et al. 2013). In summary, the European hamster has lost more than $75 \%$ of its range in most European countries. Exceptions are Hungary, where twothirds of the range remain but populations are decreasing (Bihari 2003), and Romania, in which the range seems to be largely unchanged (Hegyeli et al. 2015).

In the Western European part of the range, where conservationists and governments have been aware of the decline of European hamsters for at least $20 \mathrm{yr}$, populations are observed carefully. Such intense monitoring is not possible across the entire Eurasian range, especially since in many countries, the species, although legally protected, does not receive any active protection on the governmental level. The studies in Central and Eastern Europe, on which Fig. 1 is based, used several sources of information (Table S2 in the Supplement) which were verified by careful fieldwork.

There are only a few European countries for which no recent data exist (Fig. 1c). However, in the light of the present data, it is unreasonable to expect that the distribution and numbers of European hamsters are unchanged in unsearched parts of the range. Likewise, since searching for hamsters in thousands of hectares of agriculture fields is akin to looking for a needle in the proverbial haystack, it is possible that in some areas considered not inhabited any more, the hamsters may still be present in extremely low numbers. In Poland, an active locality was found in Lower Silesia (Auguścik \& Ziomek 2013), which was thought to be abandoned by the spe- 
cies (Ziomek \& Banaszek 2007). However, such findings do not change the general picture of the dramatic distribution decline, as small isolated populations are subjected to random demographic and genetic processes and may disappear at any moment (Banaszek et al. 2011).

Mapping an exact distribution is even more difficult when it comes to the hamster's huge eastern and Asiatic distribution area. For Russian, Belarussian, Ukrainian and Moldavian provinces, we thus compiled data on the relative occurrence of European hamsters before and after 1970. To make them comparable, we used 4 categories: extinct, rare, common and abundant. The information is based on the literature, museum data and a historic map of intense fur harvesting of European hamsters (Neronov 1965) (see Table S3 in the Supplement). 'Extinct' was assigned to a province when it was explored in numerous locations and the species was absent everywhere. This term was used with great care and was not assigned to a region when the slightest doubt existed. 'Rare' was assigned to a province if we had reports about the species' presence in 1,2 or 3 locations or if the studies did not satisfy the strict criteria for extinct. 'Common' was used when species was reported from numerous localities in a
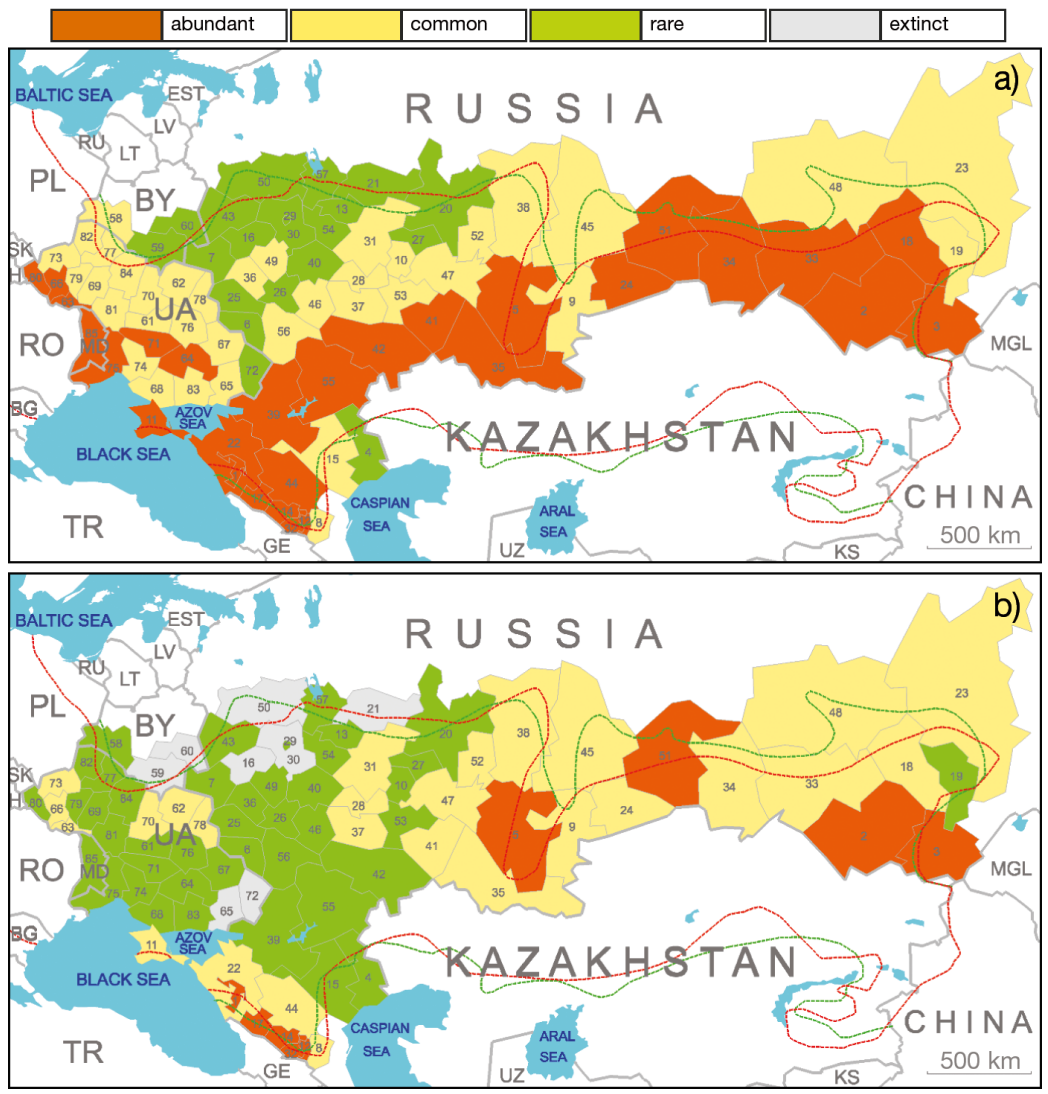

Fig. 2. Relative abundance (orange: abundant, yellow: common, green: rare, grey: extinct) of European hamsters Cricetus cricetus in their eastern range (a) before and (b) after 1970. Numbers replace the names of provinces, which are listed in Table S3 in the Supplement. The red line indicates the historical species range in the 1940s and 1950s according to Kucheruk (1959) and the green line in the 1960s according to Neronov (1965). Sources are given in Table S3 and in the Appendix. BG: Bulgaria, BY: Belarus, EST: Estonia, GE: Georgia, H: Hungary, KS: Kyrgyzstan, LV: Latvia, LT: Lithuania, MD: Moldova, MGL: Mongolia, PL: Poland, RO: Romania, RU: Russia, SK: Slovakia, TR: Turkey, UA: Ukraine, UZ: Uzbekistan province, but the numbers of individuals in these localities were low. The same accounts for 'abundant', but here the species' presence in the reported localities was notable. In this case, locals often reported hamsters in agricultural areas, in natural conditions and even in human settlements.

The density of European hamsters declined in most of the 85 provinces in this part of the distribution area (Fig. 2). Before 1970, the European hamster was abundant in 28 provinces, common in 37 and rare in 20 . Today, the species is abundant only in 8 and common in 27 provinces, but it is rare in 42 and extinct in 8 provinces.

The rate of decline of the European hamster in Ukraine, Belarus, Moldova and Russia differs between regions (Fig. 3). In some regions we see dramatic changes and even full extinction (Eastern

Europe), but in others (Caucasus and Siberia) the species is still abundant. We did not observe an increase in the relative occurrence in any province. In 37 regions, the category did not change $(0)$. Deterioration by 1 category ( -1$)$ was found in a total of 39 provinces. A severe deterioration by 2 categories $(-2)$ occurred in 9 provinces. The decline predominantly affected provinces in the west and in the south, with provinces in the southwest being most affected. This development suggests a fragmentation of populations in this part of the distribution area. When considering only areas in which the European hamster has the best chances for survival, i.e. where it is (i) common or abundant and (ii) has not declined, the maps suggest that populations will separate into 7 fragments (Fig. 4). Two are in Ukraine in the western 


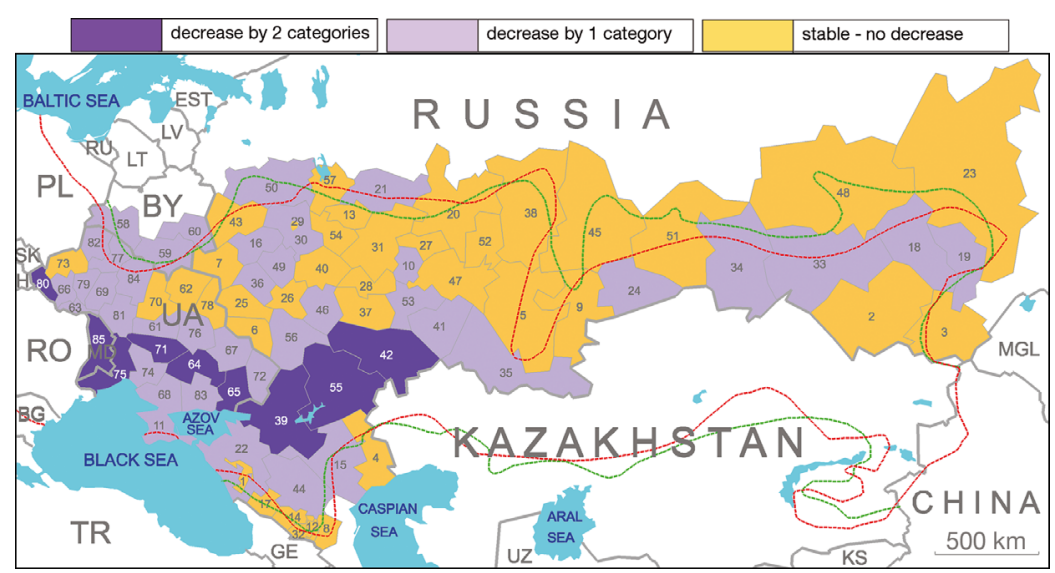

Fig. 3. Rate of decline in the relative occurrence of European hamsters Cricetus cricetus in their eastern range based on the comparison of historic (before 1970) and recent (since 1970) sources (see Table S3 in the Supplement). Literature used to create this figure is listed in the Appendix. We distinguish between densities $(0)$, moderate declines by 1 category $(-1)$ or dramatic declines by 2 categories ( -2$)$. For further details see Fig. 2

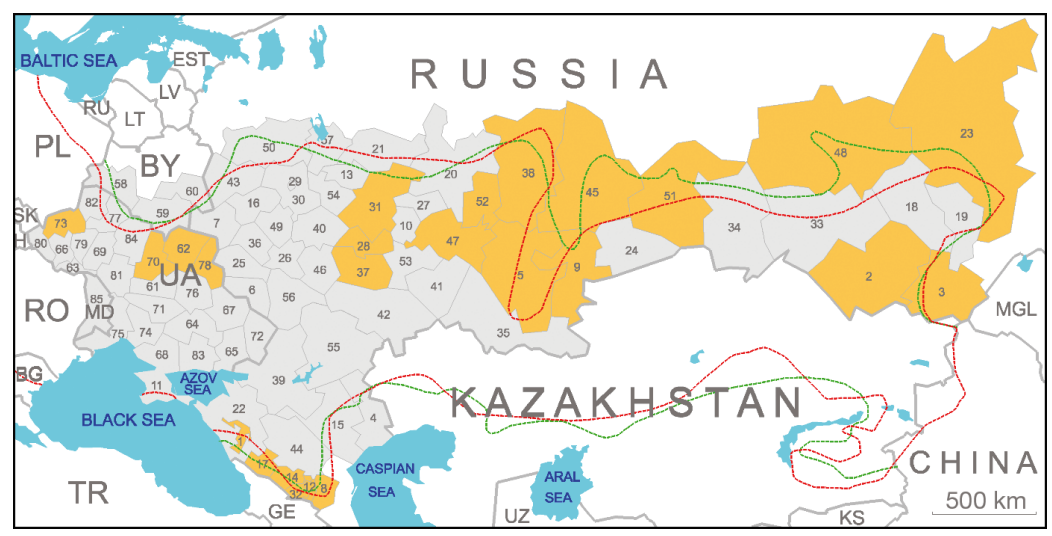

Fig. 4. Likely future occurrence of European hamsters Cricetus cricetus in Eastern Europe and Russia based on past changes in the relative abundance (see Table S3 in the Supplement). In provinces marked in yellow, hamsters are presently (i) common or (ii) abundant and not declining and should thus have better chances of survival than in other provinces. For further details see Fig. 2. For literature used to create this figure see the Appendix and Table S3

(province 73) and northern parts (provinces 70, 62, 78), which fits well with the distribution data (see Fig. 1). Of the 5 remaining fragments, 1 is mainly in the North Caucasus (provinces 17, 11, 12, 32, 8), 1 is in the western Volga region (provinces $31,28,37$ ), a large fragment is in the eastern Volga and Ural region (provinces/republics 5, 47, 52, 38, 45, 9), and 2 are in Siberia (provinces 48, 23 and province/ republic 2, 3) (Fig. 4).

From Kazakhstan we only have density data for the past (Neronov 1965) but not for the present. According to Lindeman et al. (2005), hamsters were abundant in Western Kazakhstan up to the mid-1970s. The number declined dramatically thereafter, except for a short increase between 1988 and 1990, after which the species became extremely rare. Moreover, the number of suitable habitats declined. Nevertheless, the European hamster is not in the Red Book of Kazakhstan and is not considered threatened (A. Shmalenko pers. comm.) In Kostanai oblast of Kazakhstan, the European hamster is quite common in wet biotopes within natural and grazed steppe areas (A. Shmalenko pers. comm., Oct 2015). More data on the recent distribution of European hamsters in Kazakhstan are needed.

According to Kucheruk (1959), the European hamster was present in northeastern China in the region of Xinjiang. Today the species is categorized as near threatened on the Chinese Red List, although it nearly meets the criteria for vulnerable (Smith \& Xie 2008).

Despite the declines of European hamsters in rural areas, stable populations were found in cities across the distribution area, including Brno, Košice, Lublin, Moscow, Nalchik, Omsk, Simferopol and Vienna (Feoktistova et al. 2013, Feoktistova et al. 2016) where synurbanization is observed. This shows that the factors affecting population dynamics are still unclear and must be studied in more depth.

In summary, except for very few countries such as Romania and very few regions in Ukraine and Russia, a dramatic decline in range and/or relative occurrence of the European hamster has occurred throughout its distribution area. Consequently, there is a high probability of interrupted gene flow, which has already been confirmed in many European areas (Neumann et al. 2005, Banaszek et al. 2011, La Haye et al. 2012b) where population fragments are separated by hundreds of kilometers. Highly fragmented urban areas can impair gene flow over distances as short as $2 \mathrm{~km}$ (Feoktistova et al. 2016), and this can lead to a reduction in variability; for example, colour variants of the European hamster such as flavistic, piebald, albinistic and melanistic variants have decreased since the 1950s and are now seldom reported (Kayser \& Stubbe 2000). 


\section{'Modern agriculture' seems unlikely to be the main reason for the decline}

Originally, 'modern agriculture' seemed to be the most obvious reason for the decline of European hamsters (for a review, see Weinhold 2008). However, the fact that the species declined all over the distribution area, with different landscapes, field sizes, main crops, agricultural philosophies, and under both conventional and organic or under traditional and modern farming, makes it unlikely that 'modern agriculture' is the main reason. Moreover, we could not find literature which defines the term 'modern agriculture' or which relates different agricultural practices to population densities. Experiences from hamster-friendly field management, which includes profound changes in the agricultural practices, are thus the only source of information. However, after the implementation of hamster-friendly practices, no increase in hamster numbers could be ascertained (Martens 2005, Mammen 2011b, Walz 2011, Weinhold 2011, Amand et al. 2012). Finally, the onset of the decline of the European hamster also makes it appear highly unlikely that modern agriculture is one of the main causes, since modern farming methods started much later than the decline of European hamsters. In Germany, hamsters declined as early as the 1920s (Eisentraut 1928, Petzsch 1933, Stubbe \& Stubbe 1998, Monecke 2013); in Hungary between 1960 and 1980 (Bihari 2003); and in the Omskaya oblast in Siberia in the late 1950s (Sidorov et al. 2011).

\section{No literature evidence for increased extrinsic mortality}

We could not find any literature showing that in European hamsters, the extrinsic mortality by predation or anthropogenic factors has increased. The monthly mortality rate of adults is currently rather low and is similar in both hamster-friendly $(3-17 \%$, La Haye et al. 2014; 5-19\%, Kuiters et al. 2011, both for the Netherlands) and intensely farmed large fields (depending on culture, mortality ranges from $2-7$ to $3-18 \%$ in eastern Germany, Kayser et al. 2003a). Only in 1 area in western Germany did it increase temporarily to $43 \%$ directly after harvest (Kayser et al. 2003a). These numbers are surprisingly low for a prey species.

Furthermore, the percentage of European hamsters in the diet of birds of prey such as the red kite Milvus milvus decreased from 49.5\% between 1962 and 1967 (Traue 1970) to 0 to $15 \%$ between 1992 and 2010 (Allert \& Löw 2011) in East Germany. In a Hungarian study of the eastern imperial eagle Aquila heliaca it declined from ca. $20 \%$ between 2005 and 2008 to $4 \%$ in the years 2011 and 2013 (Szabó 2013); moreover, many predators are also in decline.

In contrast, historically the extrinsic mortality of European hamsters due to fur trapping and pest control was exorbitant. Early reports of fur trapping in Germany date from the $16^{\text {th }}$ to the $19^{\text {th }}$ century (Hofmeister 1965, Stubbe \& Stubbe 1998). Between the early $20^{\text {th }}$ century and the $1970 \mathrm{~s}$, the number of hamsters trapped annually reached hundreds of thousands or even millions in many regions across Eurasia (see Table S4 in the Supplement). Fur hunting alone killed more hamsters in a region than are presently estimated to inhabit the whole of Europe. In addition, intensely targeted pest control actions against European hamsters, such as poisoning, gassing or drowning, were implemented throughout the range (Hofmeister 1965, Hubert 1968, Nechay et al. 1977, Adler \& Zimmermann 2013), which killed additional high but undefined numbers of hamsters. To our knowledge, fur hunting ceased in most countries at the latest in the 1990s, since low hamster numbers rendered trapping uneconomical. In Hungary it lasted longer, although today it is very rare (G. Nechay pers. comm.). In Russia, harvesting sharply decreased after 1970-1972. It continues to the present only in 8 regions on a very small scale. Targeted pest control actions against European hamsters have largely ceased because there is no further need. Even though European hamsters may still succumb to general rodenticides, it seems safe to assume that the 2 most severe causes of mortality in European hamsters are no longer present.

Due to increasing vehicle traffic, road mortality might have gained in importance as a reason for the decline in numbers of European hamsters. High traffic mortality was already reported in the 1960s when streets were covered with hamster cadavers in massoutbreak years (for a review, see Grulich 1980). In such a mass-outbreak year, Kemper (1967) counted 2400 dead hamsters per week on a $12 \mathrm{~km}$ long road stretch in Austria. In contrast, between 2001 and 2007, a total of only 197 hamster carcasses were found on ca. $50 \mathrm{~km}$ of country lanes in Thuringia, the region with the highest population density of European hamsters in Germany (Zimmermann 2008). As Grulich (1980) suggested, the number of road-killed hamsters seems to reflect the population densities, and thus traffic is considered to be of minor importance as a mortality factor today. 
The only indication of increased mortality is linked to the eastward shift of the oceanic-continental climate gradient leading to increasing oceanic climate in Western Europe. Historically in Germany, snow covered the ground in winter, but due to higher winter temperatures, soils are now saturated from huge quantities of rain, which affects hibernacula and food stores. In Germany, European hamsters are thus increasingly reported by locals as being active above ground in winter with their fur soaked (U. Weinhold, M. Görner pers. comm. 2015). Thus, rising winter temperatures in precipitation-rich areas such as Western Europe might increase mortality.

In summary, the literature suggests that the extrinsic mortality of European hamsters is much lower at present than historically. To what extent a climatic shift has affected mortality in recent years remains to be studied. It appears unlikely that modern farming practices are killing European hamsters on a larger scale than fur trapping and pest control did in the past.

\section{Reproduction rate has dramatically decreased}

A population is stable when the reproduction rate compensates the mortality rate. Since the extrinsic mortality of European hamsters does not seem to have increased, we reviewed literature on their reproduction rate published since 1765 from across the distribution area, i.e. embryo numbers, litter size (pups per litter) and the number of litters a female has in a year. Data until 1986, i.e. before the decline was noticed in Western Europe, are summarized as historic data, while later data are called recent data.

Most historical data came from field guides, encyclopaedias or from 'natural histories', i.e. detailed monographs on European hamsters. The recent data for number of litters and litter size come from scientific articles in which the reproduction rate of focal females was observed. Historic and recent litter numbers and litter sizes might have been measured by different techniques. Today, exact litter numbers are determined by the observation of focal females, while in historic works, farmers, who knew the local fauna, were probably the source of information. In historic times, litter size was often determined by digging out or floating a burrow. More recently, pups are counted only when they leave the maternal burrow, i.e. at an older age, reducing the chances that the litter is still complete. However, in historic studies, pups might have been overlooked in the burrow or drowned before they appeared at the surface
(Górecki 1977b). The consistency between historic and recent data of litter size (see Fig. 7) shows that the potential losses are similar with all techniques.

Data on maculae cyanae, uterine scars that indicate a previous implantation of an embryo, were not included, since it is unknown how long they stay. Their number typically ranges between 1 and 45 and might reach up to 140 (Weber \& Stubbe 1984, Grulich 1986).

Mean embryo number, assessed from dead-trapped females (historic data, Table S5 in the Supplement) or by palpation of living females (recent data, Table S6 in the Supplement), was stable until 1986: between 1925 and 1950 it was $12.00 \pm 1.08( \pm \mathrm{SEM}, \mathrm{n}=8$ studies), between 1951 and 1975, it was $12.02 \pm 1.12(\mathrm{n}=6)$, and between 1976 and 1986, it was $12.61 \pm 1.12$ $(\mathrm{n}=7$ ). After 2000, it decreased slightly to $9.95 \pm 0.83$ ( $\mathrm{n}=4$; Fig. 5). This decrease might be attributed to the different methods used. Moreover, the data show high variance, which might result from counting embryo numbers at various unknown ages of females and embryos. Embryo resorption reduces their number with increasing prenatal age (Weber \& Stubbe 1984). Moreover, embryo numbers are higher in older females (Gyurkó 1975). Females which gestate in their birth year have, on average, 5 embryos while older females have 10 (Nechay et al. 1977).

Data on number of litters and litter size are clearer. Literature sources and details are given in Tables S7S10 in the Supplement. Some articles give several data, e.g. Grulich (1980) indicated a litter number of 3 for young females and 4 to 5 for old females. In such cases, both values, 3 and 4.5, were included in the graph.

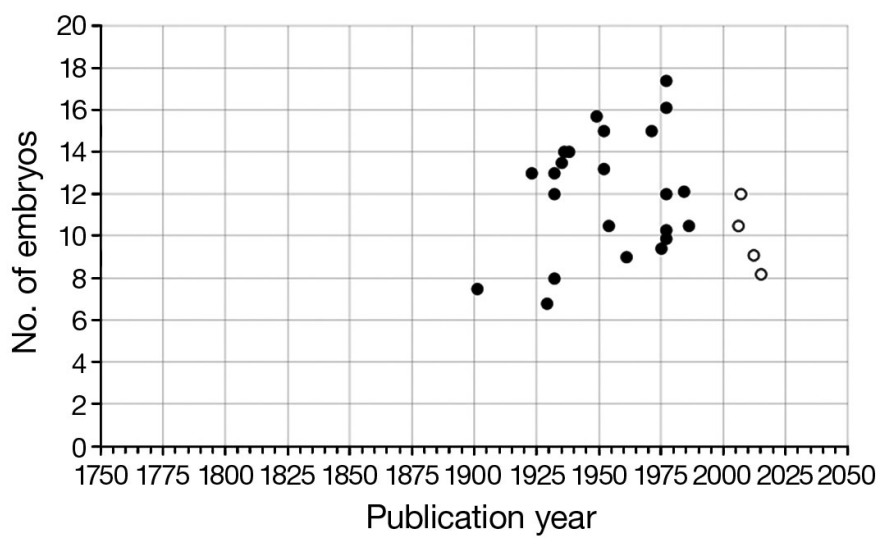

Fig. 5. Mean number of embryos in European hamsters Cricetus cricetus in various regions of their distribution area plotted against the publication year of the original studies (see Tables S5 \& S6 in the Supplement). (๑) Historic data $(\mathrm{n}=23) ;(0)$ recent data $(\mathrm{n}=4)$. Literature used to create this figure is listed in the Appendix 
Before 1986, a female produced mostly 2 to 2.5 litters per year (Fig. 6), but there was a large range from 1.5 to 4.5 between 1925 and 1985. From a modern point of view, a mean litter number of 4.5 (Nechay et al. 1977, Grulich 1980, Sládek \& Mošanský 1985) might appear too high, although 5 gestations per year have been reported for females in captivity (Samosh 1975) and are thus within the possible range. The overall mean yearly litter number from historic data was $2.46 \pm 0.1(\mathrm{n}=59$; mean $\pm \mathrm{SEM})$. In contrast, recent litter numbers are considerably lower, at $1.64 \pm 0.1(\mathrm{n}=6)$ and their range is reduced (between 1.4 and 1.9, Fig. 6). There was no east-west

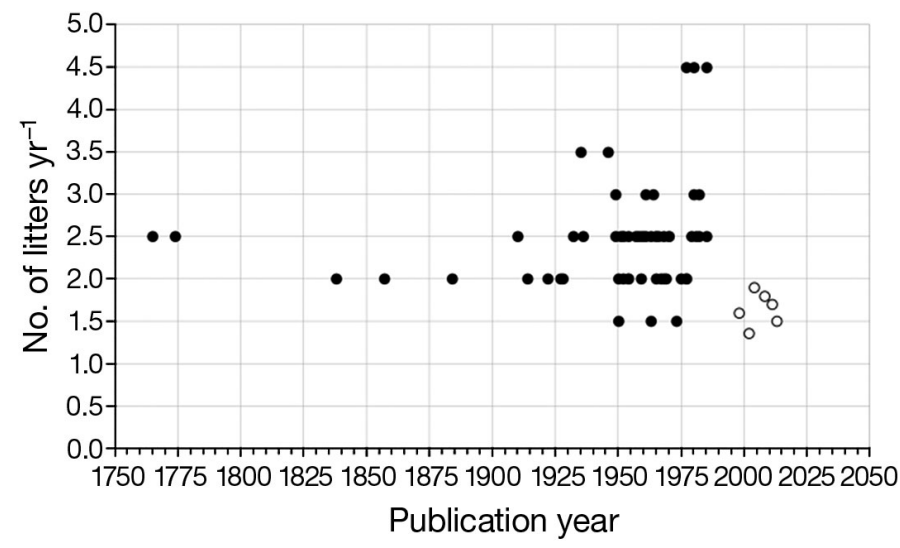

Fig. 6. Mean number of litters produced per year by European hamsters Cricetus cricetus across their distribution area plotted against the publication year of the literature source (Tables S7 \& S8 in the Supplement). (•) Historic data from 1765 until 1985 ( $\mathrm{n}=59)$; (O) recent data after 1996 $(n=6)$. Literature used to create this figure is listed in the Appendix

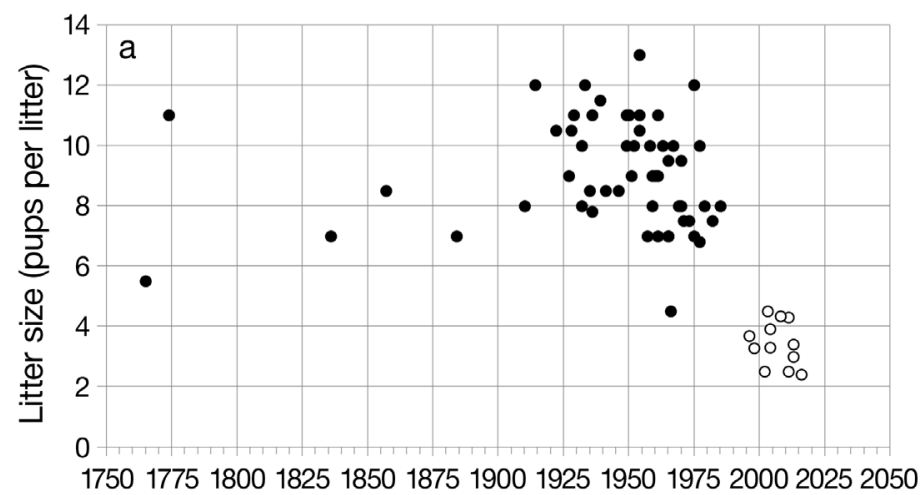

gradient in the yearly litter number as previously assumed (Leirs 2002). Mean litter numbers from historical data are: France $2.5 \pm 0.3$, Germany $2.3 \pm$ 0.1, Czech/Slovakia/Czechoslovakia $2.8 \pm 0.3$, USSR $2.2 \pm 0.1$.

The litter size before 1910 was ca. 8 (5.5-11) pups per litter (Fig. 7a). Between 1914 and 1955, a litter usually had 10 to 11 pups, but after this period, litter size decreased dramatically (Fig. 7a, Tables S9-S11 in the Supplement). To estimate the start of the decline, we performed a segmented regression analysis in Sigma Plot (SPSS) from the past $100 \mathrm{yr}$. This procedure is based on a change-point model, in which the linear relationship may change at a point that is not fixed in advance (Vieth 1989):

$$
\begin{gathered}
f_{X}=A x \leq \mathrm{t} \\
f_{X}=A+b(x-t) x>t
\end{gathered}
$$

where $f_{X}$ is the predicted value of the $n^{\text {th }}$ data point, $x$ is the $n^{\text {th }}$ time point, and $A$ is the amplitude of the plateau. Constant $b$ describes the slopes of the decrease, and $t$ is the abscissa of the change point. For further details see Monecke et al. (2006). The regression revealed that the decline started in $1954 \pm$ $4.03 \mathrm{yr}( \pm \mathrm{SE}$, Fig. $7 b)$. The data strongly suggest that this decline is ongoing. The extrapolation of the regression line points towards a litter size of 0 , i.e. an extinction of the species, in 2038; however, when the range of the data is considered, extinction could occur as early as 2020 (Fig. 7b). Theoretically, the extinction could also occur as late as 2050 (Fig. 7b), although we consider this possibility unlikely, since the reproduction rate is so low that in any year with a

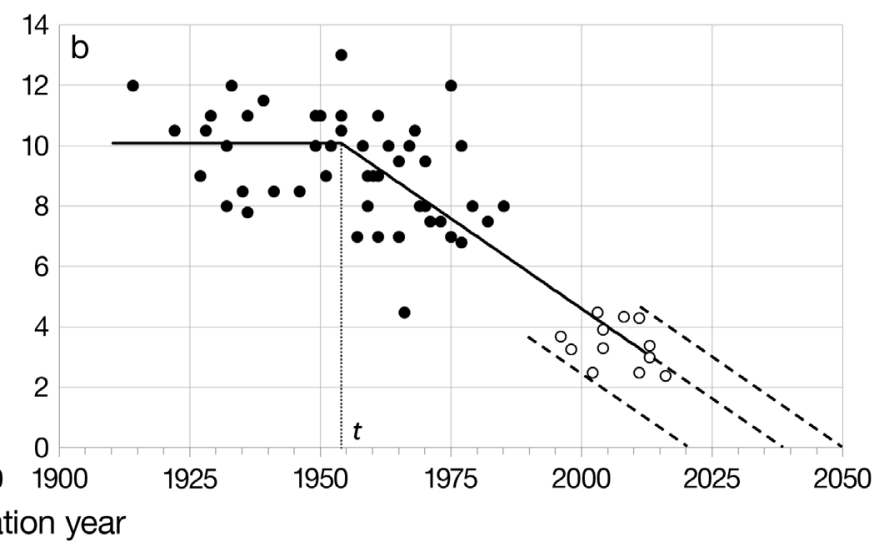

Fig. 7. Mean litter sizes in European hamsters Cricetus cricetus plotted against the publication year of the respective literature sources (Tables S9 \& S10 in the Supplement). (•) Historic data from 1765 until 1985; (O) recent data after 1995. Data are from across the distribution area. Literature used to create this figure is listed in the Appendix. (a) All data, (b) results of the segmented regression analysis. Data points from 1914 and thereafter were fitted with a regression consisting of 2 straight lines (solid) with a correlation coefficient of $r=0.84$. Their crossing point $(t)$ gives the beginning of the decline in litter size, which is in $1954 \pm 4.03 \mathrm{yr}( \pm \mathrm{SE})$. The $x$-axis crossing of the extrapolation of the regression line and its parallel translations through the upper and lower limit of the data (dashed lines) show the time frame during which the extinction of the species can be expected 
reproduction rate below average, regional populations might be so weakened that random unfavourable circumstances could lead to spontaneous extinction at any moment.

When data are split into different geographical regions, it becomes evident that this dramatic decrease in litter size affects most, if not all, regions of the distribution area (Fig. 8). Except for the former USSR, the decline rate was similar in all regions, as were the litter sizes at any given time.

That this effect is less clear in the former USSR might be due to the short time span covered by the available data. However, it might also reflect a difference in the reproduction rate between stable, declining and rapidly shrinking populations in Russian,
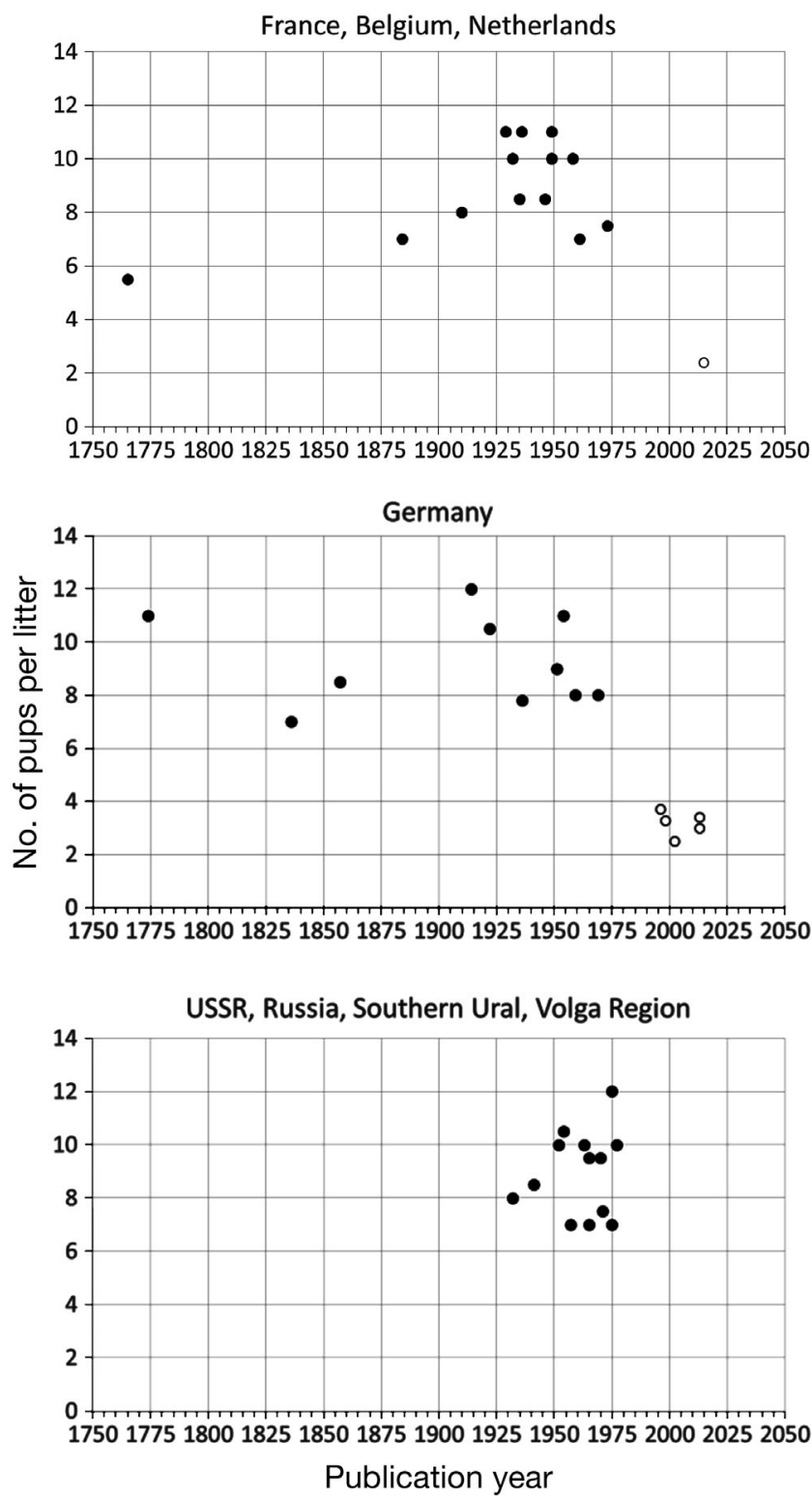

Ukrainian, Belarussian and Moldavian provinces (Fig. 4), since the data cover an enormous geographical range. Indeed, a recent review (Sidorov et al. 2011) (which was not included in the graphs on reproduction because it does not constitute original work on focal females and it is not clear whether the data originated from recent studies) gives a yearly litter number of 2 (Russia, midlands) or even 3 (southern Russia) and a mean litter size of 10.5 pups (Siberia). The extent of the data exceeds by far all recent data from studies on focal females, but the data originate from regions in which the occurrence of the European hamster is mainly stable and high (Figs. $2 \& 3$ ). A confirmation of these data and a comparison of the reproduction rate between declining and stable
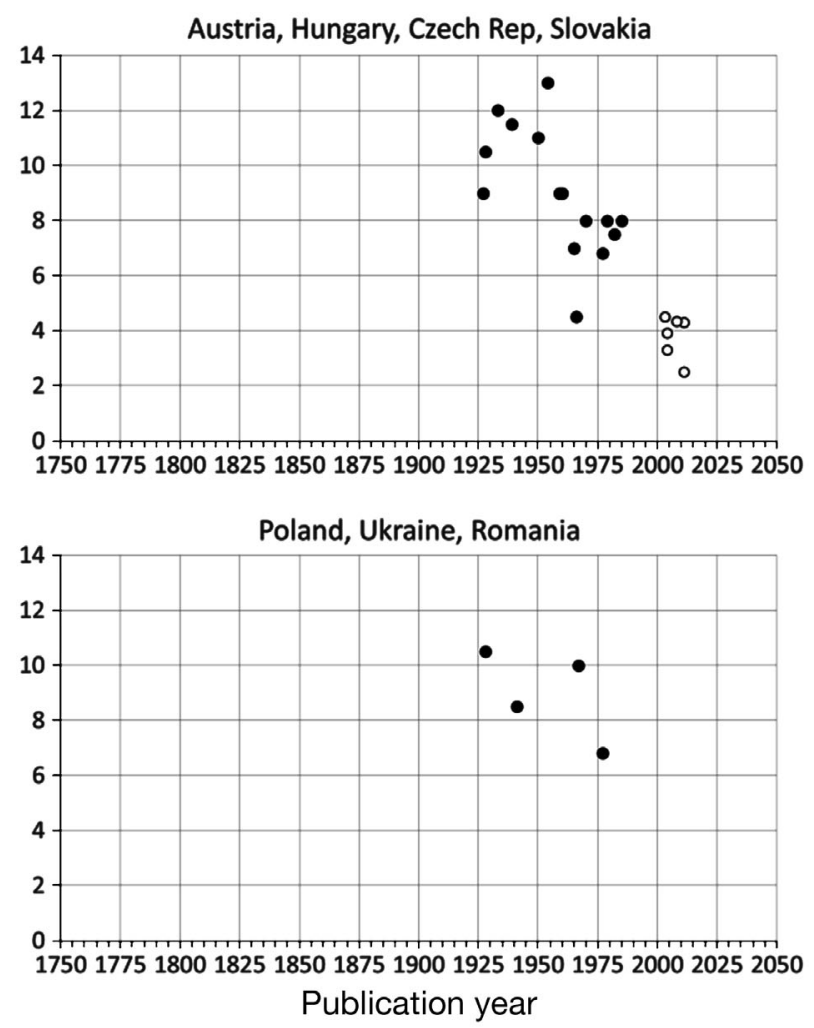

Fig. 8. Litter sizes of European hamsters Cricetus cricetus in different regions of their distribution area. For further details see 'Reproduction rate has dramatically decreased') and Fig. 7 
populations as well as between phylogeographical lineages (Neumann et al. 2005, Banaszek et al. 2010, Banaszek et al. 2012) would be highly desirable.

The yearly reproduction rate of a female is given in Table 1. Between 1914 and 1935, a female raised 25 pups per year. Between 1965 and 1985, it was only 21, due to a clear reduction in litter size, which was partly compensated by a slightly increased litter number. Between 1996 and 2015, both litter size and litter number were so reduced that a female now raises only slightly more than half of the offspring in 1 year (5.6) than it did in a single litter during the 1914-1935 period (10.2). The calculated yearly offspring number of 5.6 is supported by several field studies following focal females: Franceschini-Zink \& Millesi (2008b) found 6.3 pups, Hufnagl et al. (2011) reported 6.9 and 3.7 pups, and Albert (2013) found 5.4 pups per year and female. Recapture studies showed that no more than $20 \%$ of the pups survive until the following spring (Karaseva 1962, Górecki 1977a, Kayser \& Stubbe 2002, Franceschini-Zink \& Millesi 2008a). Given that the sex ratio is balanced (Vohralík 1974, Grulich 1986, Monecke \& Wollnik 2008), half of the pups are females, of which roughly $15 \%$ fail to reproduce (Weber \& Stubbe 1984, Franceschini \& Millesi 2004, Franceschini-Zink \& Millesi 2008b, Albert 2013). Consequently, a female effectively raises only 0.5 females for next year's reproduction (Table 1).

European hamsters can only survive as a species if each female effectively produces at least 1 female for next year's reproduction. This is no longer the case. Moreover, since in recent years the life span of European hamsters has barely exceeded the yearling state (Kayser \& Stubbe 2002, Franceschini-Zink \& Millesi 2008a), most animals have only 1 reproductive phase in their lifetime. The strong negative trend in litter size since 1954 (Fig. 7) accompanied by a

Table 1. Mean annual reproduction rates of female European hamsters Cricetus cricetus and the resulting number of reproducing females in the next year

\begin{tabular}{|c|c|c|c|}
\hline & $1914-1935$ & $1965-1985$ & $1996-2015$ \\
\hline Mean no. of litters per year and female & 2.43 & 2.56 & 1.63 \\
\hline Mean no. of pups per litter & 10.17 & 8.24 & 3.43 \\
\hline Mean no. of offspring per female and year & 24.69 & 21.11 & 5.58 \\
\hline $\begin{array}{l}\text { No. of pups that survive until the next } \\
\text { spring }\left(20 \%^{\mathrm{a}}\right)\end{array}$ & 4.94 & 4.22 & 1.12 \\
\hline No. of survivors that are female $\left(50 \%^{\mathrm{a}}\right)$ & 2.47 & 2.11 & 0.56 \\
\hline No. of surviving females that reproduce $\left(85 \%^{\mathrm{a}}\right)$ & 2.10 & 1.79 & 0.47 \\
\hline
\end{tabular}

sharply reduced litter number after 1986 (Fig. 6) closely mimics the decrease in hamster occurrence and range recorded over the past decades (see Figs. 1 \& 2) and can thus be considered as the proximate reason for the decline of this species. The ultimate reasons causing this decrease in reproduction must now be identified.

The data on the reproduction rate show that the European hamster is very close to extinction. If the reproduction rate, especially the litter size, for only a single year is lower than average, the species will become extinct. This is certainly true on a regional level, but it might also affect the whole distribution area. Studies on hamster pests revealed (1) that in outbreak years the reproduction rate and/or the duration of the reproductive phase was increased (Sládek \& Mošanský 1985, Grulich 1986) and that (2) such years occurred simultaneously over huge parts (300-4000 km) of the distribution area (Nechay 2008). Thus, the opposite scenario, viz. a high synchrony of bad years with low reproduction, might be possible, and as a result, could cause a widespread breakdown of hamster populations.

\section{IUCN STATUS OF THE EUROPEAN HAMSTER NEEDS TO BE CHANGED}

Surprisingly, the IUCN Red List status of the European hamster is Least Concern (LC) (Kryštufek et al. 2008). This categorization is mainly based on the very wide European-Asiatic range and on the assumption that the species is abundant in the eastern part of the range, especially in Russia and Ukraine (Kryštufek et al. 2008). However, this assumption was in no way based on any literature or research, but on personal communications and simple assumptions. For example, one of the authors (I. Zagorodnyuk pers. comm. in Kryštufek et al. 2008) stated personally that the species is abundant in Ukraine. However, this is quite surprising, as Gorban et al. (1998) published several years earlier that the hamster had become rare or disappeared from some parts of the country. These data were later confirmed by Rusin et al. (2013). Similarly, opinions on the species' status in Russia are simply assumptions, demonstrated in statements like: 
Less is known about the status of the species in eastern Europe and Russia, but it is certainly more abundant there than in the west (Kryštufek et al. 2008, p. 4)

even though data showing a decrease in hamster populations in several Russian provinces were already available (see Table S3). Our review shows with well established and new data that the assumptions for the present Red List categorization of the European hamster are not valid. The range and/or relative abundance of the species is rapidly shrinking all over the huge Eurasian range. The inhabited area is, or is quickly becoming, fragmented, and the number of populations is decreasing. Moreover, we have also shown a dramatic decrease in reproduction, which may cause the complete collapse of the species within a few years.

Although further research is needed, the findings on the decrease in range and relative abundance suggest that the global status of European hamsters should at least be Vulnerable (VU) according to criterion A2 of the IUCN Red List (minimum $30 \%$ of decline within $10 \mathrm{yr}$; IUCN 2012), especially since the IUCN criterion is matched that

the reduction or its causes may not have ceased or may not be understood or may not be reversible (IUCN 2012, p. 21).

The reduction in population size is based on $\mathrm{A} 1 \mathrm{a}$ and $\mathrm{c}$ criteria (direct observation and decline in area of occupancy, extent of occurrence and/or quality of habitat). If the low reproduction rate, which suggests a shrinking of the population by $50 \%$ each year in large parts of the distribution area, is also incorporated, then the status of Endangered (EN) criterion A4 might be considered:

A projected or suspected population size reduction of $\geq 50 \%$ over any 10 year period, [...] where the time period must include both the past and the future, AND where the reduction or its causes may not have ceased OR may not be understood OR may not be reversible (IUCN 2012, p. 19)

In Europe, the species is present in 18 countries, 9 of which currently consider the European hamster to be Vulnerable (VU), Endangered (EN), Critically Endangered (CR) or Extinct (EX) at the national level (Table S1). Moreover, despite reports on a severe decrease in Poland and Ukraine (Ziomek \& Banaszek 2007, Rusin et al. 2013), which also suggest the status of Endangered, the species there is still considered Data Deficient (DD) and Not Evaluated (NE), respectively. Furthermore, 14 Russian and Belorussian provinces or regions consider the European hamster as Near Threatened (NT), Vulnerable, Endangered or Critically Endangered (Table S3). None of these data support the global IUCN status of Least Concern (LC). In many of the other countries or regions the status is Data Deficient or Not Evaluated or unknown. For the sake of the species' protection it is imperative that these countries, as well as Kazakhstan and China, evaluate the range and densities of the European hamster in their area.

\section{POSSIBLE REASONS FOR THE DECLINE IN REPRODUCTION}

This review shows that the original assumptions for the decline in European hamster populations are not supported by the literature. Instead, it revealed that since about 1954, a dramatically declining reproduction rate has increasingly impaired survival of the species throughout its distribution area. The reproduction rate is already so low that it alone is sufficient to cause extinction, even if anthropogenic mortality is reduced to 0 . Research is urgently needed to identify the causes.

In general, our data suggest that the reasons for the decline in the hamsters' reproduction apply (1) all over Eurasia (2) since ca. 1954 (3) with increasing importance and (4) that they are most likely not directly related to modern agriculture. The significance of these factors might differ between regions. Some possible hypotheses which fit these characteristics are discussed in the following.

\section{Reproductive cycle of European hamsters}

To identify what might impair reproduction in wild European hamsters, a summary of the neuroendocrine processes controlling reproduction is helpful. In this species, the seasonal reproductive cycle is driven by an endogenous timing mechanism, the circannual clock, which times the onset and end of hibernation and reproduction and initiates the necessary physiological changes, even if the animals have no information about the season (for a review, see Monecke et al. 2014b). This circannual clock ticks only approximately but not exactly in a $365 \mathrm{~d}$ stroke and thus needs to be reset once per year to maintain synchrony with the environmental cycle (Gwinner 1986). This is achieved by an interaction of the circannual clock and the circadian clock, which drives daily rhythms, for example the activity rhythm. The circadian clock is located in the hypothalamic suprachiasmatic nuclei (SCN) (Dunlap et al. 2004), and one of its 
tasks is to measure the length of day or photoperiod for the circannual clock, since this is the most reliable environmental signal for seasons (Gorman et al. 2001). In mammals, the $\mathrm{SCN}$ receives the information about light or darkness from special photoreceptors in the retina, the ganglion cells, which perceive light of wavelengths around $500 \mathrm{~nm}$ (Dunlap et al. 2004).

The synchronization process in European hamsters is based on a so-called sensitive phase to short photoperiods, from mid-May to mid-July, when the shortening of photoperiod after the summer solstice is perceived (Saboureau et al. 1999). Normally, the European hamster has an arrhythmic activity pattern that is highly unpredictable for predators, but during the sensitive phase it is very precise (and risky; Monecke \& Wollnik 2005). During this period, activity starts in the late afternoon several hours before sunset, at exactly the same time each day. This precise activity onset is a stable reference to measure the tiny advances of sunset (Monecke et al. 2006) after the summer solstice. When in mid-July the shortening of the photoperiod is detected, the animals initiate gonadal regression (visible only 4 wk later; Saboureau et al. 1999), the activity pattern switches back to the default arrhythmic pattern (Monecke \& Wollnik 2005), and the circannual clock, which times the onset of the next year's reproductive phase by a complex neuroendocrine pathway (Sáenz de Miera et al. 2014), is reset (Monecke et al. 2009).

To survive in a seasonally varying environment, very precise timing is essential. The circannual clock allows the animals to anticipate the upcoming seasonal changes in the environment, so that all necessary physiological changes (at least 73 are known; Monecke et al. 2014b) from the hibernation state (Waßmer \& Wollnik 1997) to the reproductive state are completed in early spring, allowing the animals to raise their offspring during the most favourable seasons. It also allows them to anticipate the harsh winter conditions by preparing a winter stock in late summer when food abundance is high.

The above timing process might be disturbed at different points, potentially resulting in the impairment of the reproduction rate in European hamsters as observed since 1954. Indeed, several studies have reported a delay in the onset of reproduction. In a population in Austria, conception of the first litter occurred only in early to late May (Hufnagl et al. 2011), in the Netherlands from early May to early June (La Haye et al. 2014) and in Germany from early May to mid-June (Kayser \& Stubbe 2002, Weinhold \& Kayser 2006). This is a delay of 0.5 to 2 mo compared to older literature, which in general indicates
mid-April as the onset of the reproductive phase (Table S12). Such a delay severely reduces the possible number of yearly litters. Moreover, late-reproducing females have smaller litters (Hufnagl et al. 2011) so that the total number of offspring they produce in a year is lower than in early females, even if both spend the same amount of time (from the first conception to the last weaning) on reproduction (Franceschini-Zink \& Millesi 2008b).

\section{Fur harvesting}

One possible reason for a delay in reproduction might be fur trapping, although this practice ended several decades ago. More critical than the number of hamsters which were trapped was probably the timing of trapping, which occurred early in the year, since fur quality is best directly after hibernation. Thus, each year, the part of the population which terminated hibernation and started reproduction early was trapped, and this occurred over centuries.

These early-emerging animals represent the most valuable part of the population, since they have the chance to raise 3 litters in a year instead of 2. Moreover, they are the only animals which would reproduce early enough in the year for their offspring to become reproductive in their year of birth at an age of a few weeks, while later-born animals reach puberty only after months, i.e. after hibernation (Kirn 2004, Monecke et al. 2014a). The probability that these early-born animals survive until they are able to reproduce is thus much higher than that of late-born animals, of which only $20 \%$ reach the age of sexual maturity (Table 1). Animals which reproduce in their birth year have seldom been observed in recent years.

Early fur trapping may also have had an evolutionary effect. It is very likely that analogous to circadian rhythms (Ralph \& Menaker 1988, Monecke et al. 2011b), the timing of circannual rhythms has a heritable component with early- and late-reproducing genotypes (Monecke 2013). In this case, fur trapping would have caused a strong selection pressure against early-reproducing animals, which may have led to a progressive decline of animals carrying the early-reproducing genotype. Since late-reproducing females raise fewer offspring (Franceschini-Zink \& Millesi 2008b), a continuous decline in the mean litter size since 1954 and finally a reduction in the mean number of litters might be the consequence of having removed early-reproducing individuals over decades in the past. Thus, a reason for the decline in the re- 
production rate may well derive from the past. If this hypothesis is true, individual monitoring of the timing of reproduction in the wild and in breeding programmes and protection of the early-reproducing phenotype/genotype might be an effective protection measure, particularly since these animals may become crucial in the adaptation of the species to climate change.

\section{Climate change}

Following this argument, climate change induces high selection pressure against late-reproducing European hamsters. Since harvest timing has advanced due to increasing temperatures, the second litter is born around harvest (Albert 2013), so that the pups are challenged with a food shortage early in life when energy requirements are high. Survival chances of these late-born animals are considered low (Deutsche Wildtierstiftung 2014).

In general, offspring should be born when food abundance is highest. However, the increasing temperatures due to climate change induce an advance in the peak seasons of food resources, i.e. plants and insects, resulting in a temporal mismatch with the breeding phenology in vertebrates such as mammals and birds (Both et al. 2006). This occurs because the former use temperature and the latter use the unaltered seasonal changes in photoperiod as seasonal timetellers (Dunlap et al. 2004). Bird species which fail to advance their breeding phenology in adaptation to the advanced food abundance peak are in decline (Both et al. 2006, Møller et al. 2008, Husby et al. 2010, Saino et al. 2011). Some mammals have succeeded in advancing their phenology (Réale et al. 2003, Moyes et al. 2011). For example, an advanced spring emergence in recent years due to climate change has led to a strong increase in the number of the hibernating yellow-bellied marmots Marmota flaviventris (Ozgul et al. 2010). In contrast, 2 other hibernators, Columbian ground squirrels Urocitellus columbianus (Lane et al. 2012) and European hamsters (Kayser \& Stubbe 2002), have delayed their reproduction phenology and are experiencing rapid population declines.

Although climate change induces selection pressure against late-reproducing animals, it might ironically cause the disadvantageous delay in reproduction of European hamsters. Climate change has advanced cereal harvests; for example, in many French, Belgian and German regions, the harvest has advanced to June or early July. At least in these regions, it coin- cides, and might interfere, with the hamsters' phase of sensitivity to the short photoperiod and thus the resetting of their circannual clock which determines the onset of reproduction in the following spring. A case study showed that European hamsters become completely nocturnal after harvest due to a lack of cover (Wendt 1989). If they leave the burrow only at night in the summer, they would not see the advances in sunset, which are the resetting signal for the circannual clock (Monecke et al. 2006). Instead, they experience constant darkness - in the burrow during the day, and outside at night — which could be interpreted as an (extremely) short photoperiod during the sensitive phase. Such a false short day signal would be perceived too early compared to the endogenous season of the animal, resulting in a slightly premature gonadal regression (Saboureau et al. 1999), which is supported by field data (Kayser \& Stubbe 2002, Weinhold \& Kayser 2006). Such a false short day signal perceived too early in the season also causes a profound delay of the circannual clock and thus of the onset of the next reproductive phase (Monecke et al. 2009), which is also confirmed by field data (Kayser \& Stubbe 2002, Hufnagl et al. 2011, La Haye et al. 2014). Climate change could therefore account for the delay in reproduction and thus the reduction in litter numbers after 1986, since temperature has increased since the 1980s (Hartmann et al. 2013).

\section{Light pollution}

Artificial light is a global factor which is increasingly becoming a threat for animals. The decline in range (Fig. 1) and relative abundance (Fig. 3) of the European hamster shows a remarkable coincidence with highly light-polluted areas (Fig. 9). Both decline in range and relative abundance are predominantly observed in Europe and western Russia, and farther east in a stretch at the southern border of Russia. European hamsters are not only subjected to light pollution from nearby villages and street lights but also to the bright headlights of cars, which shine at eye level of these animals. Moreover, there is not only a spatial but also a temporal coincidence of increased light pollution and declining hamster populations, since the use of artificial light and its intensity increased rapidly after the Second World War. Finally, light pollution matches the criteria for identifying potential causes for the decrease in the reproduction rate: It has affected huge parts of Eurasia since the 1950s with increasing importance, and it is not related to agriculture. 


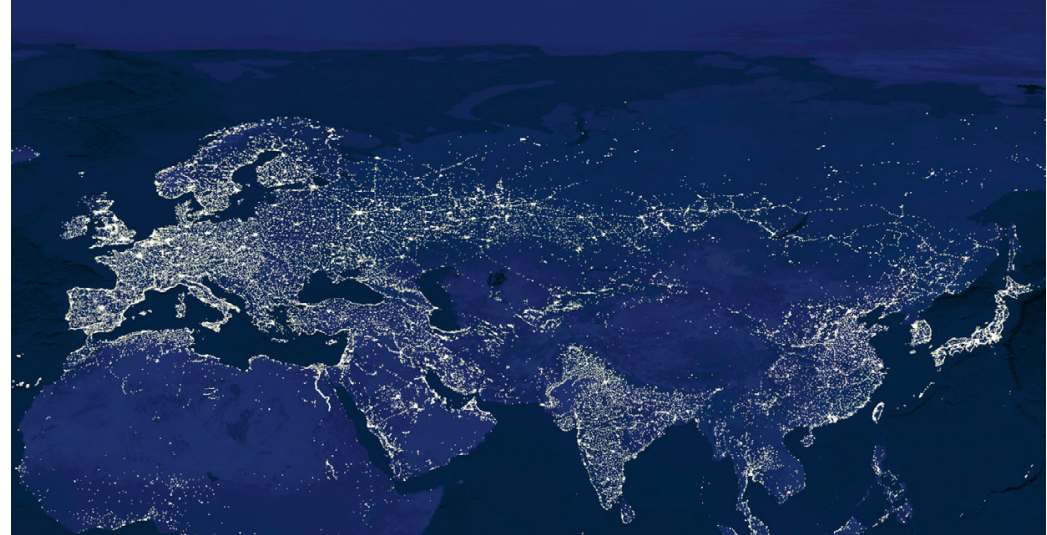

Fig. 9. Light-pollution across Eurasia. (Earthlights dmsp 1994-1995; data courtesy of Marc Imhoff [NASA GSFC] and Christopher Elvidge [NOAA NGDC]. Image by Craig Mayhew and Robert Simmon [NASA GSFC]: http://eoimages. gsfc.nasa.gov/ve//1438/land_lights_16384.tif. Licensed under Public Domain via Wikimedia Commons: https://commons.wikimedia.org/wiki/File:Earthlights _dmsp.jpg\#/media/File:Earthlights_dmsp.jpg; image has been modified to show only Eurasia)

Today, the brightness of the night sky around most urban settlements is greater than in a full moon night or than at nautical twilight (Cinzano et al. 2001). Thus, such areas never experience true nightfall. Light pollution is known to severely affect physiology and behaviour through endocrine and neurobiological processes (Navara \& Nelson 2007). Across taxa, light pollution can induce cancer or impair immunity, it can alter circadian rhythms, behaviour, energy metabolism, reproductive state and foraging/eating behaviour, and it can influence predation and migration (for a review, see Navara \& Nelson 2007, Gaston et al. 2013). Moreover, the spectral composition of street light types has changed from predominantly orange sodium-based lighting in the 1960s over metal halide lamps to high-brightness, light-emitting diodes (LEDs) with a broader spectrum of wavelengths (Gaston et al. 2013). In contrast to the sodium-based lighting, the light emitted by metal halide lamps and LEDs includes wavelengths around $500 \mathrm{~nm}$, which are perceived by the retinal ganglion cells, which in turn project to the circadian clock in the suprachiasmatic nuclei (Dunlap et al. 2004). These wavelengths are thus also relevant for the correct resetting of the circannual clock. In European hamsters, they might increasingly impair the perception of the natural shortening of the photoperiod after the summer solstice and consequently the timing of the reproductive cycle. Moreover, this environmental signal might be further blurred by the continuously increasing nightly light intensities.
In other species, light pollution initially seems advantageous, but after longer exposure it leads to profound impairment of seasonal physiology. Birds interpret light pollution as an increase in day length (Dominoni \& Partecke 2015); consequently, it advances the reproductive phase including the lay date (Kempenaers et al. 2010, Dominoni et al. 2013a, Dominoni \& Partecke 2015) and increases the extra-pair siring success (Kempenaers et al. 2010). However, after long-term exposure over $2 \mathrm{yr}$, the reproductive system of the birds fails to develop (Dominoni et al. 2013b). Likewise, Siberian hamsters Phodopus sungorus initially adapted their physiology faster to a shortening of the photoperiod under dim-light nights versus dark nights (Gorman \& Elliott 2004); however, they failed to switch completely to the winter phenotype (Ikeno et al. 2014). In Siberian hamster pups, a brief nightly illumination of only $15 \mathrm{~min}$ on postnatal Day 18 induced gonadal growth (Spears et al. 1990) even though the animals were maintained under a short photoperiod and should have been in a winter state.

In European hamsters, artificial light during 2 nights in winter shifted the circannual reproductive cycle by 3 to 4 wk (Monecke et al. 2010). Outdoors, they showed a slightly modified activity pattern in an urban versus a rural area in July and August (Kaim et al. 2013). Since the activity pattern changes profoundly at this time of the year, it might indicate a difference in the seasonal timing of reproduction and thus its success. Light pollution may therefore present a hitherto underestimated threat for European hamsters and other species.

\section{Fragmentation of the landscape}

Highly light-polluted areas are usually highly fragmented by streets, highways and railway tracks. The coincidence between the maps showing the decline of European hamsters (Figs. $1 \& 3$ ) and the light-pollution map (Fig. 9) might thus be a result of the coincidence of population decline and habitat fragmentation, which has been discussed to be a reason for the decline of many species (Hanski 1998), including European hamsters (Weinhold 2008). Besides a risk for increased mortality due to traffic 
and a long-term reduction in genetic diversity due to isolation (Neumann et al. 2004, Feoktistova et al. 2016) habitat fragmentation might pose an additional possible threat to reproduction. In captive European hamster colonies, higher litter sizes were observed after a male from another colony was introduced (La Haye et al. 2012a, L. Heimann pers. comm., S. Monecke unpubl. obs.), possibly due to an increase in genetic variability. In general, the genetic diversity of European hamster populations is low (La Haye et al. 2012b). Since even comparably small natural barriers, such as a $20 \mathrm{~km}$ belt of sandy soils, are able to separate 2 huge phylogeographical lineages of the European hamster (Banaszek et al. 2012), it is likely that the increasing number of artificial barriers is insurmountable. In highly structured urban areas, distances as short as $2 \mathrm{~km}$ isolate different demes of hamsters (Feoktistova et al. 2016). Fragmentation might thus be another reason for the ongoing decrease in the reproduction rate.

\section{Population density}

A similar case in history when a dramatic decline in reproduction led to the extinction of a severe pest and game species is illustrated by the passenger pigeon Ectopistes migratorius. Once probably the world's most abundant bird species, passenger pigeons declined within a century from several billions of birds per flock to extinction in 1914 (Frenz 2012). A recent model calculation found that habitat loss did not play a role in the decline of passenger pigeons; neither did hunting, except when it impacted reproduction. Instead, a failure to reproduce was identified as the primary reason for the decline (Stanton 2014). One hypothesis is that steadily declining population densities increasingly failed to stimulate reproduction. There is a striking similarity between the fate of passenger pigeons and the decline of European hamsters (Hutterer \& Geiger-Roswora 1997, Monecke 2013). The decline of hamsters might have started with overhunting leading to decreasing population densities, which negatively affected the reproduction rate. This hypothesis is supported by extremely high population densities, an extended reproductive phase and high numbers of juveniles in pest years (Grulich 1986).

However, observations by Sludsky (1977) suggest that an increased mortality rate supports a high reproduction rate. At present, we observe low rates of both mortality and reproduction. The effect of den- sity and mortality on the reproduction rate remains to be studied. An effective protection measure might be to cause an artificial hamster pest situation by releasing high numbers of captive-bred hamsters in small areas and follow the reproductive success of the population.

\section{Pesticides}

The use of pesticides increased rapidly after the Second World War. Simultaneously, reproduction of the European hamster decreased, suggesting a causal relationship. In the American mink Mustela vison, reproduction rates and embryo numbers decreased due to exposure to polychlorinated biphenyls (Aulerich \& Ringer 1977). Various persistent organochlorines used in pesticides, among them DDT and Dieldrin, have been detected in the tissue of European hamsters, although the concentrations barely exceeded the detection limit (Kayser et al. 2001). Likewise, only traces of lead, cadmium, mercury and copper could be detected (Kayser et al. 2003b). These results were thus considered not dangerous for the hamster or its reproduction. Moreover, if these agrochemicals were responsible for reduced embryo numbers, one would expect an increase in the reproduction rate after the ban of such pesticides in many countries (e.g. in Germany, DDT and Dieldrin were banned in the 1970s), which did not happen. Furthermore, the number of embryos produced by European hamsters has decreased only slightly and only very recently (Fig. 5). Thus, agrochemicals do not appear very likely to be the main cause for a reduction in the reproduction rate of European hamsters.

\section{Decrease in lifespan}

Older European hamster females produce a larger number of embryos (Gyurkó 1975), larger litter sizes (Monecke et al. 2011a) and more litters (Grulich 1980) as yearlings. They also emerge earlier from hibernation (Ružić 1976) and can reproduce earlier. However, in recent years, it has been reported from many regions that wild European hamsters barely exceed the yearling stage (Kayser \& Stubbe 2002, Franceschini-Zink \& Millesi 2008a, participants of the International Hamster Workgroup pers. comm.). This potential decrease in lifespan is not caused by a higher extrinsic mortality, such as predation or anthropogenic reasons, but rather by unknown intrinsic reasons such as cancer (Ghadially \& Illman 1965, 
Brandes et al. 2004) or other predispositions, since even in captivity, the mean lifespan is currently only 1 to $1.5 \mathrm{yr}$ for males and 1.5 to $2 \mathrm{yr}$ for females ( $\mathrm{S}$. Monecke unpubl. obs.), and this is only rarely exceeded (Monecke et al. 2011a, Wenisch \& Godman 2011). According to its physiology as a circannual hibernator, this species should have a lifespan of several years, and this is indeed stated in older literature (Mohr 1954, Karaseva 1962, Reznik et al. 1976, Nechay et al. 1977, Ernst et al. 1989). A possible decrease in lifespan might thus be a major reason for the species' decline and might explain the lower reproduction rate. In accordance with this suggestion, a recent study found remarkable parallels with our study for body weight, which has also declined since the 1950s (Tissier et al. 2016). This might reflect a younger mean age or a poorer fitness of the animals. Both would lower the reproduction rate of the animals.

\section{CONCLUSIONS}

This literature review does not exclude the possibility that particular agricultural practices increase the mortality of European hamsters; however, it shows that reduced fecundity is a far better explanation for the decline of this species than an increased mortality due to changes in agricultural practices. The continuous decrease in the reproduction rate is so severe that it alone is sufficient to cause extinction within an extremely short period of time, but the factors which negatively affect the reproduction rate still need to be identified. Without considering mortality, our data suggest an extinction of the species between the years 2020 and 2038. Thus, fundamental research is presently the most important protection measure to develop effective protection strategies in the short remaining time and should thus have highest priority. Conservation breeding programmes for the weakest populations might buy some additional time and postpone local extinctions of hamsters by a few more years. The decline in European hamster populations may have started with overhunting and continued as the result of an ongoing decline in the reproduction rate. Modern farming practices seem less likely to be responsible for losses than threats acting on the genetics (reduced genetic variability or potential extinction of an early-breeding genotype) or physiology (climate change, light pollution, altered age structure) of the animals. We strongly recommend immediately changing the IUCN Red List status of European hamsters from Least Concern to Vulnerable or even Endangered.
Acknowledgements. Our study was done under the framework of the IUBS/ISZS International Research Program: Biological Consequences of Global Change (BCGS). We thank Marcel Visser (NIOO, the Netherlands) for sparking the idea for this literature research. We are very grateful for the committed literature search by the interlibrary loan service of the library of the Karlsruhe Institute of Technology (KIT, Germany), especially by Nadia Zappe, the University of Heidelberg (Germany) and Petra Widmer from Motz \& Kadner Literature Service (Germany). Further, we thank the German National Library in Leipzig, the State Library of Baden, Karlsruhe (Germany), the State Museum of Natural History Karlsruhe (Germany), Carina Siutz (University of Vienna, Austria), Clara Stefen (Senckenberg Natural Historic Collections, Dresden, Germany), Gabor Nechay (Gödöllő, Hungary), Maurice La Haye (Radboud University of Nijmegen, the Netherlands), Mikhail Rusin (National Academy of Science, Kiev, Ukraine), Stefani Martens (Großrettbach, Germany) and Ulrich Weinhold (Institute for Faunistic, Heiligenkreuzsteinach, Germany). We also thank Ilse E. Hoffmann (University of Vienna, Austria), Jennifer Hatlauf (University of Natural Resources and Life Sciences Vienna, Austria), Elke Schmelzer (Nature Conservation Alliance Burgenland, Austria), Ayona Shmalenko and Sergey Sklyarenko (Association for the Conservation of Biodiversity of Kazakhstan) for their help in obtaining distribution data and also Dr. Valery Neronov (Severtsov Institute of Ecology and Evolution, Moscow) who provided us with unique data on fur harvesting of European hamsters in the former USSR and with a number of respondents from the regions, reserves and universities for recent information. We are also grateful for excellent transcription and translation services by Stepan Khalimonov and Dina Ershova (University of Hohenheim, Stuttgart, Germany) as well as for the revision of the English by Katrin Monecke (Wellesley College, USA).

\section{LITERATURE CITED}

Adler S, Zimmermann W (2013) Der Feldhamster (Cricetus cricetus L.) als wiederholte Plage der Landwirtschaft in den Stadtfluren von Gotha (1885-1904) und der Ruf nach Gift [The Common hamster (Cricetus cricetus L.) as a repeated agricultural pest in the town-meadows of Gotha (1885-1904) and the call for poison]. Artenschutzreport 31:28-33

Albert M (2013) Erfassung des Reproduktionserfolges des Feldhamsters (Cricetus cricetus) in Hessen [Logging the reproductive success of female European hamsters (Cricetus cricetus) in Hesse]. MSc thesis, Forschungsinstitut Senckenberg / Justus-Liebig University, Gießen

Allert J, Löw S (2011) Rotmilan (Milvus milvus) als Prädator vom Feldhamster (Cricetus cricetus) im Landkreis Gotha (Thüringen, Deutschland) [Red kite (Milvus milvus) as a predator of the Common hamster (Cricetus cricetus) in the administrative district of Gotha (Thuringia, Germany). Säugetierkd Inf 8:149-153

Amand B, Duponteil A, Strosser P, Boos M (2012) Plan national d'actions en faveur du hamster commun Cricetus cricetus 2012-2016 [National actions plan for the Common hamster Cricetus cricetus 2012-2016]. Ministère de l'Ecologie du Développement durable et de l'Energie, Paris

Ambros M, Baláž I, Janálová D (2003) Occurrence of hamster (Cricetus cricetus L., 1758) in western Slovakia. In: 
Nechay G (ed) Proc 11th Meeting of the International Hamster Workgroup, Budapest

Anděra M, Horáček I (1982) Poznáváme naše savce [Getting to know our mammals]. Mladá fronta, Prague

Andreychev AV, Kuznetsov VA (2012) Mlekopitayushchie Mordovii [Mammals of Mordovia]. Mordovia State University, Saransk

Aubry JR (1961-1962) Notes sur le hamster [Notes on the hamster]. Bull Soc Hist Nat Colmar 30:25-28

Auguścik L, Ziomek J (2013) Confirmation of the locality of the Common hamster in the central part of Lower Silesian province. In: Ziomek J, Dobrosława A, Eichert U, Kardynia P, Bajaczyk R (eds) Proc 20th meeting of the International Hamster Workgroup. Kontekst, Poznań, p 27

Aulerich RJ, Ringer RK (1977) Current status of PCB toxicity to mink, and effect on their reproduction. Arch Environ Contam Toxicol 6:279-292

Babina SG (2009-2010) Itogi inventarizatsii teriofauny zapovednika 'Kuznetskiy Alatau' [Results of a theriofauna inventory of the 'Kuznetskiy Alatau' reserve]. www.kuzalatau.ru/articles/download/21 (accessed on 21 September 2016)

Baldaev FK (ed) (2002) Redkie i ischezayushchie vidy zhivotnyh [Rare and endangered species of animals]. Izdatelstvo Mariyskogo Poligrafkombinata, Yoshkar-Ola

Banaszek A, Jadwiszczak KA, Ratkiewicz M, Ziomek J, Neumann K (2010) Population structure, colonization processes and barriers for dispersal in Polish Common hamsters (Cricetus cricetus). J Zool Syst Evol Res 48: 151-158

Banaszek A, Jadwiszczak KA, Ziomek J (2011) Genetic variability and differentiation in the Polish Common hamster (Cricetus cricetus L.): genetic consequences of agricultural habitat fragmentation. Mamm Biol 76:665-671

Banaszek A, Ziomek J, Jadwiszczak KA, Kaczyńska E, Mirski P (2012) Identification of the barrier to gene flow between phylogeographic lineages of the Common hamster Cricetus cricetus. Acta Theriol (Warsz) 57:195-204

Bašenina N, Gruzdev V, Dukelskaja N, Šilov I (1957) Gryzuny - vrediteli sadov i ogorodov [Rodent pests of orchards and vegetable gardens]. Moskovskogo Universiteta, Moscow

Bašenina N, Gruzdev V, Dukelskaja N, Šilov I (1961) Gryzuny - vrediteli sadov i ogorodov [Rodent pests of orchards and vegetable gardens]. Moskovskogo Universiteta, Moscow

Bayanov MG, Kucherov EB (1995) Zhivotny mir Bashkortostana [Wildlife of Bashkortostan]. Kitap, Ufa

Berdyugin KI, Bolshakov VN (1998) The Common hamster (Cricetus cricetus L.) in the eastern part of the area. In: Stubbe M, Stubbe A (eds) Ökologie und Schutz des Feldhamsters [Ecology and protection of the European hamster]. Martin-Luther-University Halle-Wittenberg, Halle/ Saale, p 43-79

Bihari Z (2003) Regression in distribution of hamster (Cricetus cricetus) in Hungary during the past fifty years. In: Nechay G, Schreiber R, La Haye M (eds) Proc 11th, 14th and 15th Meeting of the International Hamster Workgroup, Budapest, Hungary (2003), Munsterschwarzach, Germany (2006) and Kerkrade, the Netherlands (2007), Part I. Alterra/Radboud University Nijmegen, Wageningen/ Nijmegen, p 27-30

Blasius JH (1857) Naturgeschichte der Säugethiere Deutschlands und der angrenzenden Länder von Mitteleuropa
[Natural history of mammals of Germany and adjacent countries of Central Europe], Vol 1: Säugethiere. Friedrich Vieweg und Sohn, Braunschweig

Bobrinskiy NA, Kuznetsov BA, Kuzyakin AP (1965) Opredelitel mlekopitayushchikh SSSR [The mammals of the USSR]. Prosveschenie, Moscow

Bolšhakov V (1977) Zveri Urala [Mammals of the Urals]. Sredneuralskoe knizhnoe izdatelstvo, Sverdlovsk

> Both C, Bouwhuis S, Lessells CM, Visser ME (2006) Climate change and population declines in a long-distance migratory bird. Nature 441:81-83

Botnariuc N, Tatole V (eds) (2005) Cartea Roşie a vertebratelor din România [Red book of the vertebrates of Romania]. Muzeul Naţional de Istorie Naturală Grigore Antipa, Bucharest

Brandes K, Fend F, Monecke S, Teifke JP, Breuer W, Hermanns W (2004) Comparative morphologic and immunohistochemical investigation of spontaneously occurring thymomas in a colony of European hamsters. Vet Pathol 41:346-352

Brehm A (1914) Brehms Tierleben [Brehm's animal life], Vol 11, Säugetiere, 2. Band. Bibliographisches Institut Meyer, Leipzig

Buffon GLL (1765) Le hamster [The hamster]. In: Histoire naturelle générale et particulière: avec la description du Cabinet du Roy [General and specific natural history with a description of the 'Cabinet du Roy'], Book XIII. Imprimerie royale, Paris, p 117-134

Bundesamt für Naturschutz (2013) Verbreitungsgebiete der Pflanzen- und Tierarten der FFH-Richtlinie [Distribution of plant and animal species of the FFH guidelines]. Bundesamt für Naturschutz, Bonn. www.bfn.de/fileadmin/ MDB/documents/themen/natura2000/Nat_Bericht_2013/ Arten/saeugetiere_ohne_fledermaeuse_neu.pdf

Čanády A (2013) New site of the European hamster (Cricetus cricetus) in the urban environment of Košice city (Slovakia). Zool Ecol 23:61-65

Chebakova IV (ed) (1996) Smolenskoye poozerye biosferni reservat [Biosphere reserve 'Smolensk poozerye']. Reference book of National Parks of Russia, Center of wildlife protection, The Biodiversity Conservation Center, Moscow. http://oopt.info/index.php?oopt=1163 (accessed on 13 October 2015)

Cinzano P, Falchi F, Elvidge CD (2001) The first World Atlas of the artificial night sky brightness. Mon Not R Astron Soc 328:689-707

Demyanchik VT (2004) Obyknovenny khomyak [The Common hamster]. In: Krasnaya kniga Respubliki Belarus. Zhivotnye. Redkie i nakhodyashchiesya pod ugrozoy isceznoveniya vidy dikikh zhivotnykh [The Red Book of animals of the Republic of Belarus. Rare and endangered species of wild animals]. Belaruskaya entsiklopedia imeni Petrusya Brovki, Minsk

Deutsche-Wildtierstiftung (2014) Jahresbericht 2014-Die Arbeit der Deutschen Wildtierstiftung [Annual report 2014 - The work of the German Wildlife Foundation]. Deutsche Wildtierstiftung, Hamburg

Didier R, Mathias P (1936) Le hamster (Cricetus cricetus (L.) - notes biologiques [The hamster (Cricetus cricetus (L.) - biological notes]. Mammalia 1:15-23

Didier R, Rode P (1935) Les mammifères de France [Mammals of France]. Sociéte nationale d'acclimatisation de France, Paris

Dominoni DM, Partecke J (2015) Does light pollution alter daylength? A test using light loggers on free-ranging 
European blackbirds (Turdus merula). Philos Trans R Soc Lond B Biol Sci 370:20140118

Dominoni D, Quetting M, Partecke J (2013a) Artificial light at night advances avian reproductive physiology. Proc R Soc Lond B Biol Sci 280:20123017

Dominoni DM, Quetting M, Partecke J (2013b) Long-term effects of chronic light pollution on seasonal functions of European blackbirds (Turdus merula). PLOS ONE 8: e85069

Dukelskaja NM, Stepanova VI (1932) Nekotoryye dannyye po biologii khomyaka i sposobam bor'by s nim [Contributions to the knowledge of the biology of the hamster and methods for its control]. Bull Plant Prot 4:55-64

Dunlap JC, Loros JL, DeCoursey PJ (2004) Chronobiology: biological timekeeping. Sinauer Associates, Sunderland, MA

Dupond C (1932) La propagation du hamster en Belgique [The dispersion of hamsters in Belgium]. Bull Mus R Hist Nat Belg 8:1-43

Eisentraut M (1928) Über die Baue und den Winterschlaf des Hamsters (Cricetus cricetus L.) [On burrows and hibernation in the hamster (Cricetus cricetus L.)]. Z Saugetierkd 3:172-208

Enzinger K, Gross M, Berg HM, Werdenich D (2010) Aktionsplan - Feldhamster (Cricetus cricetus) in Österreich unter besonderer Berücksichtigung Niederösterreichs [Action plan for Common hamsters (Cricetus cricetus) in Austria, with particular consideration of Lower Austria]. Naturschutzbund NÖ, Vienna

Eóry M (1959) Adatok a közönséges hörcsög (Cricetus cricetus Linné) kölykeinek fejlödéséhez [Data on the development of the Common hamster (Cricetus cricetus Linné) pups]. Vertebr Hung 1:195-207

Ernst H, Kunstyr I, Rittinghausen S, Mohr U (1989) Spontaneous tumours of the European hamster (Cricetus cricetus L.). Z Versuchstierkd 32:87-96

Fedorowicz Z (1928) Krajowe zwierzęta ssące [Mammals of Poland]. Nakładem i drukiem Józefa Zawadzkiego, Wilno

Feoktistova NY, Surov AV, Tovpinetz NN, Kropotkina MV and others (2013) The Common hamster as a synurbist: a history of settlement in European cities. Zool Pol 58: 113-126

Feoktistova NY, Meschersky IG, Surov AV, Bogomolov PL, Tovpinetz NN, Poplavskaya NS (2016) Genetic structure of urban population of the Common hamster (Cricetus cricetus). Russ J Genet 52:194-203

Feriancová-Masárová Z, Hanák V (1965) Stavovce Slovenska IV [Vertebrates of Slovakia]. Cicavce-Vydavatel'stvo Slovenskej Akadémie Vied, Bratislava

Flint VE, Čugunov JO, Smirin VM (1965) Mlekopitayushchie SSSR [Mammals of the USSR]. Mysil, Moscow

Flint VE, Čugunov JO, Smirin VM (1970) Mlekopitayushchie SSSR [Mammals of the USSR]. Mysil, Moscow

Franceschini C, Millesi E (2004) Reproductive timing and success in Common hamsters. In: Losinger I (ed) Proc 12th meeting of the International Hamster Workgroup, Office National de la Chasse et de la Faune Sauvage (ONCFS), Strasbourg, p 63-66

Franceschini-Zink C, Millesi E (2008a) Population development and life expectancy in Common hamsters. In: Millesi E, Winkler H, Hengsberger R (eds) Biosystematics and Ecology Series. Proc 13th meeting of the International Hamster Workgroup (2005) The Common hamster (Cricetus cricetus): perspectives on an endangered spe- cies. Austrian Academy of Sciences Press, Vienna, p 45-49

Franceschini-Zink C, Millesi E (2008b) Reproductive performance in female Common hamsters. Zoology (Jena) 111:76-83

Frechkopf S (1958) Faune de Belgique-Mammifères [Fauna of Belgium-mammals]. Institut Royal des Sciences Naturelles de Belgique, Brussels

Frenz L (2012) Lonesome George oder das Verschwinden der Arten [Lonesome George, or The disappearance of species]. Rowohlt, Berlin

Gaffrey G (1961) Merkmale der wildlebenden Säugetiere Mitteleuropas [Characteristics of the wild mammals of Central Europe]. Akademische Verlagsgesellschaft Geest \& Portig, Leipzig

Gaston KJ, Bennie J, Davies TW, Hopkins J (2013) The ecological impacts of nighttime light pollution: a mechanistic appraisal. Biol Rev Camb Philos Soc 88:912-927

Gelashvili DB, Ushakov VA, Slepov AV, Dmitriev AI (1999) Ekologicheskaya harakteristika melkih mlekopitayushchih nizhegorodskogo zavolzhya [Ecological characteristics of mammals of the Nijegorodsk Transvolga region]. Vestnik nizhegorodskogo universiteta imeni Lobachevskogo. Nijegorodsky State University, Nijniy Novgorod, p 51-59

Geptner VG, Morozova-Turova KG, Calkin VL (1950) Vrednyje i poleznyje zveri rajonov polezaščitnych nasaždenij [Harmful and useful mammals of regions with field-protective vegetation]. Moscow University Press, Moscow

Gerber R (1951) Nagetiere Deutschlands [Rodents of Germany]. Akademische Verlagsgesellschaft Geest \& Portig/ Ziemsen Verlag, Leipzig

Gershenson S (1941) Additional data concerning the mating system in wild populations of Common hamster (Cricetus cricetus L.). C R Acad Sci URSS 31:155-156

Gershenson S (1945a) Evolutionary studies on the distribution and dynamics of melanism in the hamster (Cricetus cricetus L.). I. Distribution of black hamsters in the Ukrainian and Bashkirian Soviet Socialist Republics (USSR). Genetics 30:207-232

Gershenson S (1945b) Evolutionary studies on the distribution and dynamics of melanism in the hamster (Cricetus cricetus L.). II. Seasonal and annual changes in the frequency of black hamsters. Genetics 30:233-251

Gershenson S (1945c) Rasprostranenie chernyh homyakov v USSR [Distribution of black hamsters (Cricetus cricetus L.) in the Ukraine]. Dok Akad Nauk SSSR 47:622-625

Gershenson S (1945d) Sezonnye izmeneniya chastoty chernyh homyakov [Seasonal changes in distribution dynamics of black hamsters]. Dok Akad Nauk SSSR 48: 709-712

Ghadially FN, Illman O (1965) Naturally occurring thymomas in the European hamster. J Pathol Bacteriol 90: 465-469

Glas P (1961) De Hamster (Cricetus cricetus L.) in ZuidLimburg [The hamster (Cricetus cricetus L.) in SouthLimburg]. Levende Nat 64:77-81

Glotov IN (1969) Rasprostranenie i chislennost myshevidnykh gryzunov. In: Biologicheskoe rayonirovanie Novosibirskoy oblasti [Distribution and abundance of Muroidea. In: Biological differentiation of Novosibirsk province]. Nauka, Novosibirsk, p 33-58

Gorbachev SN (1915) Mlekopitayushchie orlovskoj gubernii po novym dannym 1910-1914 [Mammals of Orlov guberny based on new data 1910-1914]. In: Materialy k 
poznaniyu prirody Orlovskoj gubernii [Data on the natural history of Orlov guberny]. Obshestvo issledovatelei prirody Orlovskoj gubernii, Orel

Gorban I, Dykiy I, Srebrodolska E (1998) What has happened with Cricetus cricetus in Ukraine? In: Stubbe M, Stubbe A (eds) Ökologie und Schutz des Feldhamsters [Ecology and protection of the European hamster]. Martin-Luther-Universität Halle-Wittenberg, Halle/Saale, p 87-89

Górecki A (1977a) Consumption by and agricultural impact of the Common hamster Cricetus cricetus (L.), on cultivated fields. Bull OEPP 7:423-429

Górecki A (1977b) Energy flow through the Common hamster population. Acta Theriol (Warsz) 22:25-66

Gorman MR, Elliott JA (2004) Dim nocturnal illumination alters coupling of circadian pacemakers in Siberian hamsters, Phodopus sungorus. J Comp Physiol A Neuroethol Sens Neural Behav Physiol 190:631-639

Gorman MR, Goldman BD, Zucker I (2001) Mammalian photoperiodism. In: Takahashi JS, Turek FW, Moore RY (eds) Handbook of behavioral neurobiology: circadian clocks. Book 12. Kluwer Academic/Plenum Publishers, New York, NY, p 481-508

Grizmek B (1969) Der Feldhamster [The European hamster]. In: Eibl-Eibesfeldt I, Eisentraut M, Freye HA, Grizmek B and others (eds) Grizmeks Tierleben: Enzyklopädie des Tierreiches [Grizmeks animal life: encyclopedia of the animal kingdom], Book 11 Mammals (2). Kindler Verlag, Zürich, p 310-315

Gromov IM, Gureev AA, Novikov GA, Sokolov II, Strelkov PP, Chapskiy KK (1963) Mlekopitayushchie fauny SSSR chast' 1 [Mammalian fauna of the USSR - part 1], Academy of Science of the USSR, Zoological Institute, Moscow and Leningrad

Grulich I (1975) Zum Verbreitungsgebiet der Art Cricetus cricetus (Mamm.) in der Tschechoslowakei [On the distribution area of the species Cricetus cricetus (Mamm.) in Czechoslovakia]. Zool Listy 24:197-222

Grulich I (1980) Populationsdichte des Hamsters (Cricetus cricetus, Mamm.) [Population density of the hamster (Cricetus cricetus, Mamm.)]. Acta Sci Nat Brno 14:1-44

Grulich I (1986) The reproduction of Cricetus cricetus (Rodentia) in Czechoslovakia. Acta Sci Nat Brno 20:1-56

Guryleva GM (1968) Ecologicheskie komplexy mlekopitayushchikh (zonalnie aspecty) v Ulianovskoy, Penzenskoy i Saratovskoy oblastyakh [Ecological complexes of mammals (zonal aspects) in Ulyanovsk, Penza and Saratov provinces]. In: Voprosi biogeografii Srednego i Nijnego Povoljya. Saratov State University, Saratov, p 259-266

Gwinner E (1986) Circannual rhythms, Vol 18. Springer Verlag, Berlin

Gyurkó P (1975) Biológiai vizsgálatok és kormeghatározasi lehetöségek hörcsögön (Cricetus cricetus L.) [Biological studies and possibilities of age determination in the Common hamster (Cricetus cricetus L.)]. Novenyvedelem (Bp) 11:10-14

Hainard R (1949) Les mammifères sauvages d'Europe [The wild mammals of Europe], Vol II. Delachaux \& Niestlé S. A., Neuchatel

Hamar M (1967) Din viata rozatoarelor [On the life of rodents]. Editura ştiințifică, Bucharest

Hamar M, Theiss F, Marin D (1959) Cercetari asupra raspindirii, ecologiei si combaterii hirciogului (Cricetus cricetus L. (1758)) in RPR [Research on the geographic distribution, the ecology and the fight against the ham- ster (Cricetus cricetus L. (1758)) in the People's Republic of Romania]. Ann Inst Cercet Agron Ser C 27:199-212

Hanski I (1998) Metapopulation dynamics. Nature 396: 41-49

Hanzák J (1970) Naši savci [Our mammals]. Albatros, Prague

Hartmann DL, Klein Tank AMG, Rusticucci M, Alexander LV and others (2013) Observations: atmosphere and surface. In: Stocker TF, Qin D, Plattner GK, Tignor M and others (eds) Climate change 2013: the physical science basis. Contribution of Working Group I to the Fifth Assessment Report of the Intergovernmental Panel on Climate Change. Cambridge University Press, Cambridge, p 159-254

Hediger H (1944) Die Jugendentwicklung des Hamsters (Cricetus cricetus L.) [Ontogeny of the hamster (Cricetus cricetus L.)]. CIBA Z 93:3327-3328

Hegyeli Z, Kecskés A, Korbut Z, Banaszek A (2015) The distribution and genetic diversity of the Common hamster (Cricetus cricetus) in central and western Romania. Folia Zool (Brno) 64:173-182

Hofmeister K (1965) Die Praxis der Hamsterbekämpfung [The practice of hamster control]. Diploma, FriedrichSchiller-University, Jena

Hubert K (1968) Erfahrungen mit der Hamsterbekämpfung in den Bezirken Halle und Magdeburg [Experiences with hamster control in the districts of Halle and Magdeburg]. Hercynia — Ökol Umwelt Mitteleur 5:181-192

Hufnagl S, Franceschini-Zink C, Millesi E (2011) Seasonal constraints and reproductive performance in female Common hamsters (Cricetus cricetus). Mamm Biol 76: $124-128$

Husby A, Nussey DH, Visser ME, Wilson AJ, Sheldon BC, Kruuk LE (2010) Contrasting patterns of phenotypic plasticity in reproductive traits in two great tit (Parus major) populations. Evolution 64:2221-2237

Husson AM (1949) Aantekeningen over de hamster [Notes on the hamster]. Natuurhist Maandblad 38:111-115

Hutterer R, Geiger-Roswora D (1997) Drastischer Bestandsrückgang des Feldhamsters, Cricetus cricetus, in Nordrhein-Westfalen [Drastic population decline of the European hamster, Cricetus cricetus, in North RhineWestphalia]. Abh Westf Mus Naturkd 59:71-82

Ikeno T, Weil ZM, Nelson RJ (2014) Dim light at night disrupts the short-day response in Siberian hamsters. Gen Comp Endocrinol 197:56-64

Ilin VY, Bystrakov NV, Dobrolyubov AN, Ermakov OA and others (2006) Konspect fauny mlekopitayushikh Penzenskoy oblasti [Report on mammalian fauna of Penza province]. In: Izvestia of Penza State Pedagogical University, Book 5. Penza State Pedagogical University, Penza

Isaev IV, Dmitriev AV (eds) (2010) Krasnaya kniga Chuvashskoy respubliki. Tom 1. Chast' 2. Redkie i ischezayushchie vidy zhivotnyh [Rare and endangered species of animals, Vol 1, Part 2]. GUP IPK Chuvashiya, Cheboksary

IUCN (2012) IUCN Red List categories and criteria: Ver 3.1, $2^{\text {nd }}$ edn. IUCN, Gland

Ivanchev VP, Kazakova MV (eds) (2011) Krasnaya kniga Ryazanskoj oblasti. Izdanie vtoroe [Red Book of the Ryazan Region], $2^{\text {nd }}$ edn. Golos gubernii, Ryazan

Jennison G (1929) Tableau des périodes de gestation et du nombre de jeunes [Table of gestation period and number of young]. Rev Hist Nat Appl 10:119-122

Kaim I, Hędrzak M, Ziewacz Ł (2013) Daily activity pattern 
of the Common hamster (Cricetus cricetus) at two localities situated in urban and rural areas. Zool Pol 58:59

Kapitonov VI (2009) Geograficheskoe rasprostranenie mlekopitayushchikh v Udmurtii [Geographical distribution of mammals in Udmurtia]. In: Sovremennye problemy zoo- i filogeografii mlekopitayushchikh May 14-20, 2009 (Abstr) [Proc Modern objectives of zoo- and phylogeography of mammals]. Proceedings of the Conference. KMK, Moscow, p 36

Karaseva EV (1962) Izuchenie s pomoshyu mecheniya osobennostey ispolzovaniya territorii obyknovennogo khomyaka v Altayskom kraye. [A study of the pecularities of territory utilization by the hamster in the Altai territory carried out with the use of labelling. Zool Zh 41:275-285

Karaseva EV, Telitsina AY, Samoilov BL (1999) Mlekopitayushchie Moskvy v proshlom i nastoyaschem [Mammals of Moscow in the past and in the present]. Nauka, IPEE, Moscow

Karpenko NT (2013) Problema sokhranenia redkikh i ischezauschikh vidov Bogdinsko-Baskunchakskogo zapovednika [Conservation of rare and endangered species of the Bogdinsko-Baskunchakski reserve]. Samarskaya Luka: problems of regional and global ecology 22:122-127

Kayser A, Stubbe M (2000) Colour variation in the Common hamster Cricetus cricetus in the north-eastern foot-hills of the Harz Mountains. Acta Theriol (Warsz) 45:377-383

Kayser A, Stubbe M (2002) Untersuchungen zum Einfluss unterschiedlicher Bewirtschaftung auf den Feldhamster Cricetus cricetus (L.), einer Leit- und Charakterart der Magdeburger Börde. [Investigations on the impact of different field-management practices on the European hamster Cricetus cricetus (L.), a characteristic species of the Magdeburger Börde]. Ministerium für Raumordnung, Landwirtschaft und Umwelt, Halle

Kayser A, Voigt F, Stubbe M (2001) First results on the concentrations of some persistent organochlorines in the Common hamster Cricetus cricetus (L.) in SaxonyAnhalt. Bull Environ Contam Toxicol 67:712-720

Kayser A, Stubbe M, Weinhold U (2003a) Mortality factors of the Common hamster Cricetus cricetus at two sites in Germany. Acta Theriol (Warsz) 48:47-57

Kayser A, Voigt F, Stubbe M (2003b) Metal concentrations in tissues of Common hamsters (Cricetus cricetus [L.]) from an agricultural area in Germany. Bull Environ Contam Toxicol 70:509-512

Kempenaers B, Borgström P, Loës P, Schlicht E, Valcu M (2010) Artificial night lighting affects dawn song, extrapair siring success, and lay date in songbirds. Curr Biol 20:1735-1739

Kemper H (1967) Einige Freilandbeobachtungen am Hamster (Cricetus cricetus L. 1758) [Some outdoor observations of the hamster (Cricetus cricetus L. 1758)]. Saugetierkdl Mitt 15:165-169

Kiku VF, Uspenskaya IG, Burlaku VI, Georgitsa SD and others (2011) Structura naseleniya melkikh mlekopitayushchikh Moldovy [Species composition of small mammal populations in Moldova]. Zool J 90:223-231

Kirikov SV (1952) Pticy i mlekopitayushchie v usloviyah landshaftov yuzhnoj okonechnosti Urala [Birds and mammals of the most southern area of the Urals]. Academia nauk SSSR, Moscow

Kirn N (2004) Ontogenese des europäischen Feldhamsters (Cricetus cricetus) unter dem Einfluß verschiedener präund postnataler Photoperioden [Ontogeny of the European hamster (Cricetus cricetus) under the influence of different pre- and postnatal photoperiods]. Doctoral dissertation, University of Veterinary Medicine Hannover

Köhler U, Geske C, Mammen K, Martens S, Reiners TE, Schreiber R, Weinhold U (2014) Maßnahmen zum Schutz des Feldhamsters (Cricetus cricetus) in Deutschland [Measures towards the conservation of the Common hamster (Cricetus cricetus) in Germany]. Nat Landschaft 89:344-349

Konstantinov VA (ed) (2006) Zhivotnye [Animals], Vol 2. Istoki, Voronezh

Korbut Z, Rusin MY, Banaszek A (2013) The distribution of the Common hamster (Cricetus cricetus) in western Ukraine. Zool Pol 58:99-112

Kowalski K (1964) Klucze do oznaczania kręgowców Polski: Ssaki-Mammalia [Key to the identification of Polish vertebrates: mammals-Mammalia], Part 5. Państwowe wydawnictwo Naukowe Warszawa, Kraków

Kratochvíl J (1966) Použitá zoologie-Obratlovci [Applied zoology - vertebrates]. Státni zemědělské nakladatelstvi, Praha

Kryshtal AP (1929) Novi materiali s biologii khomyaka [New data on the biology of the hamster]. Nat Hist News 1/2: 42-54

Kryštufek B, Vohralík V, Meinig H, Zagorodnyuk I (2008) Cricetus cricetus. IUCN 2011, Red List of Threatened Species, Version 2011.2., e.T5529A11273957. www.iucn redlist.org/details/5529/0 (accessed on 17 May 2016)

Kucheruk VV (1959) Stepnoi faunisticheski komplex mlekopitayushchikh I ego mesto $\mathrm{v}$ faune Palearctiki [Faunal composition of steppe mammals and its role in Palaearctic fauna] In: Formozov AN (ed) Geography of terrestrial animals and methods to study them. Akademia nauk SSSR, Moscow, p 45-87

Kuilik IL (1962) Materialy k ekologii obyknovennogo homyaka na Altae [Data pertaining to the ecology of the Common hamster in the Altai area]. Bull MOIP 67:16-25

Kuiters AT, La Haye MJJ, Müskens GJDM, van Kats RJM (2011) Perspectieven voor een duurzame bescherming van de hamster in Nederland [Perspectives for sustainable protection of the hamster in the Netherlands]. Alterra Wageningen UR, Wageningen

Kuzmin LL (2006) Mlekopitayushchie Vladimirskoy oblasti. Fauna, ecologia, okhrana [Mammals of the Vladimir region. Fauna, ecology and protection]. Service-Print, Vladimir

Kuznecov VA (1952) Fauna mlekopitayushchikh Moldavii [Mammalian fauna of Moldavia]. Dok Mold Fil Akad Nauk SSSR 4-5:111-150

Kuznetsov BA (1975) Opredelitel' pozvonochnich zhivotnych fauny SSSR- chast' 3 Mlekopitayushchie [Characteristics of vertebrate fauna in the USSR, Part 3, mammals]. Prosveshcheniye, Moscow

La Haye M, Müskens G (2014) Basisrapport voor een soortenbeschermingsprogramma voor de hamster in Vlaanderen [Basic report for a species protection programme for the hamster in Flanders]. Bureau van de Zoogdiervereniging, Nijmegen

La Haye MJJ, Koelewijn HP, Siepel H, Verwimp N, Windig JJ (2012a) Genetic rescue and the increase of litter size in the recovery breeding program of the Common hamster (Cricetus cricetus) in the Netherlands. Relatedness, inbreeding and heritability of litter size in a breeding program of an endangered rodent. Hereditas 149:207-216

La Haye MJJ, Neumann K, Koelewijn HP (2012b) Strong decline of gene diversity in local populations of the 
highly endangered Common hamster (Cricetus cricetus) in the western part of its European range. Conserv Genet 13:311-322

La Haye MJJ, Swinnen KRR, Kuiters AT, Leirs H, Siepel H (2014) Modelling population dynamics of the Common hamster (Cricetus cricetus): timing of harvest as a critical aspect in the conservation of a highly endangered rodent. Biol Conserv 180:53-61

Lane JE, Kruuk LEB, Charmantier A, Murie JO, Dobson FS (2012) Delayed phenology and reduced fitness associated with climate change in a wild hibernator. Nature 489:554-557

Laptev IP (1958) Mlekopitayushchie taezhnoj zony Zapadnoj Sibiri [The mammals of the taiga zone in Western Siberia]. Tomsk State University, Tomsk

Larina NI, Golikova VL, Denisov VP, Devishev RA (1968) Vidovie soobshestva I rasprostranenie mlekopitayushchikh [Species composition and distribution of mammals]. In: Biogeography of Middle and Lower-Volga region. Saratov State University, Saratov, p 105-132

Laussmann H, Fabry A (2008) EU-kofinanzierte Förderprogramme des Naturschutzes in Thüringen im Zeitraum von 2007 bis 2013 [EU-co-financed support programmes for nature conservation in Thuringia for the period 2007 to 2013]. Landschaftspflege Naturschutz Thüringen 45: $15-24$

Le Louarn H, Saint Girons MC (1977) Les rongeurs de France [The rodents of France]. Institut National de la Recherche Agronomique, Paris

Leirs H (2002) Conservation advices based on rodent pest biology: the case of the hamster. In: Mercelis S, Kayser A, Verbeylen G (eds) Proc 10th Meeting of the International Hamster Workgroup. Natuurpunt Studie, Tongeren, p 82-84

Lindeman GB, Abaturov BD Bykov AV, Lopushkov VA (2005) Dinamica naselenia pozvonochnikh jivotnikh zavoljskoy polupustyni [Population dynamics of vertebrates in the Trans-Vologa semidesert]. Russian Academy of Sciences, Moscow

Lovassy S (1927) Magyarország gerinces állatai és gazdasagi vonatkozásaik. [Vertebrate fauna of Hungary and its economic importance]. AKM Természettudományi Társulat, Budapest

Lozan MN (1971) Gryizuny Moldavii - Istoriya stanovleniya Fauny i ekologii retsentnyik vidov [Rodents of Moldova history of faunal evolution and the ecology of recent species], Vol 2. Academy of Science of the Moldavian SSR, Shtiintsa, Kishinev

Lyapunov AN (2008) K rasprostraneniyu obyknovennogo khomyaka na territorii Kirovskoy oblasti [Distribution of the Common hamster (Cricetus cricetus) in the Kirov region]. In: Problems of regional ecology in conditions of stable development, Part 1. O-kratkoe, Kirov, p 169-170

Mammen K (2011a) Ist der Feldhamster in Sachsen noch zu retten? [Can the European hamster be rescued in Saxony?]. In: Dauderstädt U (ed) Proc Feldhamster in Sachsen. NABU-Landesverband Sachsen, Leipzig

Mammen U (2011b) Elf Jahre feldhamsterfreundlich bewirtschaftete Ausgleichsfläche [Ecological compensation area under hamster-friendly management: results after 11 years]. In Dauderstädt U (ed) Proc Feldhamster in Sachsen. NABU-Landesverband Sachsen, Leipzig

Manninger GA (1960) Szántóföldi növények állati kártevői Különös tekintettel a nagyüzemi védekezésre [Animal pest species of arable crops - with special focus on their broad suppression]. Mezôgazdasági kiadó, Budapest

Markov G (1998) Information on the recent status of Common hamster (Cricetus cricetus L.) in Bulgaria. In: Stubbe M, Stubbe A (eds) Ökologie und Schutz des Feldhamsters [Ecology and protection of the European hamster]. Martin-Luther-Universität Halle-Wittenberg, Halle/Saale, p 99-100

Martens S (2005) Ergebnisse einer fünfjährigen Untersuchung am Feldhamster (Cricetus cricetus) in Thüringen [Results of a 5-year study of the European hamster (Cricetus cricetus) in Thuringia]. Säugetierkd Inf 5: 553-568

Martin R (1910) Atlas de poche des mammifères de France, de la Suisse romane et de la Belgique: avec leur description, moeurs et organisation suivi d'une étude d'ensemble sur les mammifères [Pocket guide to mammals of France, western Switzerland and Belgium with descriptions, habits and organisation based on a comprehensive study of mammals]. L. Lhomme, Paris

Marvin MY (1968) Opreditel Gryizunov Urala [Field guide of the rodents from the Ural]. Ural State University of A.M. Gorky, Sverdlovsk

Marvin MY (1966) Myshevidnye gryzuny severnyh rajonov srednego Urala [Mouse-like rodents in the northern areas of the Middle Urals]. Uch Zap UrGU 47:12-22

Melnikov VN, Buslaev SV (2012) Obyknovennyj kanyuk v Vostochnom Verhnevolzh'e [The Common buzzard in the Eastern Upper Volga Region]. In: Kanyuki Severnoj Evrazii: rasprostranenie, sostoyanie populyacij, biologiya. Trudy VI Mezhdunarodnoy konferencii po sokoloobraznym i sovam Severnoi Evrazii. Krivoi Rog / Melnikov VN (eds) [Buzzards of North Eurasia: distribution, population status, biology. Proc 6th Int Conf on Birds of Prey and Owls of North Eurasia]. Tsentr-Print, Kryviy Rih, p 108-121

Meyer M (2009) Feldhamster Cricetus cricetus (Linnaeus, 1758). [The European hamster Cricetus cricetus (Linnaeus, 1758)]. In: Hauer S, Ansorge H, Zöphel U (eds) Atlas der Säugetiere Sachsens [Atlas of the mammals of Saxony]. Sächsisches Landesamt für Umwelt, Landwirtschaft und Geologie, Dresden, p 216-219

Minoransky VA, Dobrovolsky OP (2013) Proshloe i nastoyaschee ohotnichih mlekopitayuschih Nizhnego Dona [Past and present status of mammalian game species of the Lower Don River]. Foundation, Rostov-on-Don

Mironov NP, Karpuzidi KS, Klimehko IZ, Kolesnikov IM and others (1965) Istochniki i perenoschiki chumy i tulyaremii [Reservoirs and vectors of plague and tularaemia]. Meditzina, Moscow

Mishta AV, Sitnikova EF (2005) Obyknovenny homyak na yugo-vostoke Bryanskoy oblasti [The Common hamster in the SE of Bryansk province]. Fedotov YP (ed) In: Izuchenie i okhrana biologicheskogo raznoobrazia Bryanskoy oblasti [Study and conservation of biodiversity of Bryansk province]. Part 1. Kirillitsa, Trubchevsk, p 160-162

MKULNV (Ministerium für Klimaschutz, Umwelt, Landwirtschaft, Natur- und Verbraucherschutz des Landes Nordrhein-Westfalen) (2013) Leitfaden 'Umsetzung des Artenschutzes gemäß $§ 44$ Abs. 4 BNatSchG in der Landwirtschaft in Nordrhein-Westfalen' [Guideline 'Implementation of wildlife conservation according to $\S 44$ Abs. 4 BNatSchG (Federal Law for Nature Conservation) in agriculture of North Rhine-Westphalia']. MKULNV, Düsseldorf 
Mohr E (1954) Die freilebenden Nagetiere Deutschlands und der Nachbarländer [Wild rodents of Germany and adjacent countries]. VEB Gustav Fischer Verlag, Jena

Møller AP, Rubolini D, Lehikoinen E (2008) Populations of migratory bird species that did not show a phenological response to climate change are declining. Proc Natl Acad Sci USA 105:16195-16200

Monecke S (2013) All things considered? Alternative reasons for hamster extinction. Zool Pol 58:41-47

Monecke S, Wollnik F (2005) Seasonal variations in circadian rhythms coincide with a phase of sensitivity to short photoperiods in the European hamster. J Comp Physiol B Biochem Syst Environ Physiol 175:167-183

Monecke S, Wollnik F (2008) How to increase the reproductive success in European hamsters - shiftwork in the breeding colony. In: Millesi E, Winkler H, Hengsberger R (eds) Biosystematics and ecology series. Proc 13th Meeting of the International Hamster Workgroup (2005) The Common hamster (Cricetus cricetus): perspectives on an endangered species. Austrian Academy of Sciences Press, Vienna, p 97-114

Monecke S, Malan A, Wollnik F (2006) Asymmetric control of short day response in European hamsters. J Biol Rhythms 21:290-300

Monecke S, Saboureau M, Malan A, Bonn D, Masson-Pévet M, Pévet P (2009) Circannual phase response curves to short and long photoperiod in the European hamster. J Biol Rhythms 24:413-426

Monecke S, Malan A, Saboureau M, Pévet P (2010) Phase shift of the circannual reproductive rhythm in European hamsters by 2 days of long photoperiod. Neuroendocrinol Lett 31:738-742

Monecke S, Bonn D, Reibel-Foisset S, Pévet P (2011a) Breeding success in aged female Common hamsters (Cricetus cricetus). Säugetierkd Inf 8:121-129

Monecke S, Brewer JM, Krug S, Bittman EL (2011b) Duper: A mutation that shortens hamster circadian period. J Biol Rhythms 26:283-292

Monecke S, Amann B, Lemuth K, Wollnik F (2014a) Dual control of seasonal time keeping in male and female juvenile European hamsters. Physiol Behav 130:66-74

Monecke S, Wollnik F, Pévet P (2014b) The circannual clock in the European hamster. How is it synchronized by photoperiodic changes? In: Numata H, Helm B (eds) Annual, lunar and tidal clocks - patterns and mechanisms of nature's enigmatic rhythms. Springer Japan, Tokyo, p 277-308

Morozova-Turova LG (1938) Mlekopitayushchie Mordovskogo zapovednika [Mammals of the Mordovia reserve]. In: Smidovich PG (ed) Fauna of Mordovia State Reserve. Committee for reservation, Moscow, p 17-36

Moskvitina NS, Sushkova NG (1988) Mlekopitayushchie tomskogo priobya i sposoby ih izucheniya [Mammals of the Pre-Ob area, Tomsk region, and how to study them]. Tomsk State University, Tomsk

Moyes K, Nussey DH, Clements MN, Guinness FE and others (2011) Advancing breeding phenology in response to environmental change in a wild red deer population. Glob Change Biol 17:2455-2469

Munteanu A (1998) Some data on number, peculiarity and ecology of Cricetus cricetus L. (Rodentia) in the Republic Moldova. In: Stubbe M, Stubbe A (eds) Ökologie und Schutz des Feldhamsters [Ecology and protection of the European hamster]. Martin-Luther-Universität HalleWittenberg, Halle/Saale, p 90
Müskens GJDM, van Kats RJM, Kuiters AT (2003) Reintroduction of the Common hamster, Cricetus cricetus, in the Netherlands, preliminary results. In: Nechay G, Schreiber R, La Haye M (eds) Proc 11th, 14th and 15th Meeting of the International Hamster Workgroup, Budapest, Hungary (2003), Munsterschwarzach, Germany (2006) and Kerkrade, the Netherlands (2007), Part I. Alterra/Radboud University Nijmegen, Wageningen/ Nijmegen, p 33-40

Muzaev VM (ed) (2013) Krasnaya kniga Respubliki Kalmykia. T. 1. Zhivotnye [Red book of Republic of Kalmykia. Vol 1. Animals], Dzhangar, Elista

Myasnikov YA (1977) Mlekopitayushchie Tulskoy oblasti [Mammals of Tula province]. Priokskoe printhouse; Zoological museum of Moscow State University, Tula

Navara KJ, Nelson RJ (2007) The dark side of light at night: physiological, epidemiological, and ecological consequences. J Pineal Res 43:215-224

Nechay G (2000) Status of hamsters Cricetus cricetus, Cricetus migratorius, Mesocricetus Newtoni and other hamster species in Europe, Vol. 106. Council of Europe, Strasbourg

Nechay G (2008) Peak numbers of Cricetus cricetus (L.): Do they appear simultaneously? In: Millesi E, Winkler $H_{\text {, }}$ Hengsberger R (eds) Biosystematics and Ecology Series. Proc 13th Meeting of the International Hamster Workgroup (2005) The Common hamster (Cricetus cricetus): perspectives on an endangered species. Austrian Academy of Sciences Press, Vienna, p 69-77

Nechay G, Hamar M, Grulich L (1977) The Common hamster (Cricetus cricetus [L.]); a review. Bull OEPP 7: 255-276

Negrobov OP (ed) (2011) Krasnaya kniga Voronezhskoy oblasti. V. 2. Zhivotnye [Red book of Voronrzh province. Vol 2. Animals]. Voronezh State University, Voronezh

Nehring A (1901) Die Zahl der Zitzen und der Embryonen bei Mesocricetus und Cricetus [Number of teats and embryos in Mesocricetus and Cricetus]. Zool Anz 24: $130-131$

Neronov VM (1965) Issledovanie struktury arealov obyknovennogo khomyaka i vodyanoy krisy na territprii SSSR [Study of the range structure of Common hamster and European water vole in the USSR]. PhD thesis, Gamaleay Institute of Epidemiology and Microbiology, Moscow

Neronov VM, Prokofieva ZV (1969) Vidovoy sostav i chislennost gryzunov v raznikh landshaftakh Stavropolia [Species composition and abundance of rodents in different landscapes of Stavropol]. Advances of the All-Union Research Institute of Biological Plant Protection 30: 140-168

Neumann K, Kayser A, Gattermann R, Jansman H, Maak S (2004) Multiple bottlenecks in threatened western European populations of the Common hamster Cricetus cricetus (L.). Conserv Genet 5:181-193

Neumann K, Kayser A, Mundt G, Gattermann R, Michaux JR, Maak S, Jansman HAH (2005) Genetic spatial structure of European Common hamsters (Cricetus cricetus)a result of repeated range expansion and demographic bottlenecks. Mol Ecol 14:1473-1483

Niethammer J (1982) Cricetus cricetus (Linnaeus, 1758) Hamster (Feldhamster). In: Niethammer J, Krapp F (eds) Handbuch der Säugetiere Europas [Handbook of the mammals of Europe], Book 2/1 Rodentia II. Akademische Verlagsgesellschaft, Wiesbaden, p 7-28 
Novikova EV, Novikov EA (2007) Khomyak obyknovenni v gorodskikz i prigorodnykh mestoobitaniyakh g. Omska [Common hamster in urban and suburban habitats of Omsk] In: Rozhnov VV (ed) Proc Theriofauna of Russia and adjacent territories. KMK, Moscow, p 334

Ognev SI (1916) Mlekopitayushchie Tavricheskoy gubernii, preimushestvenno Krymskogo poluostrova [Mammals of Tavria governorate, mainly the Crimean peninsula]. In: Zapiski Krymskogo obschestva estestvoispytateley i lubiteley prirody V5, Part 1, Rodentia. Simferopol, p 30-33

Oken L (1838) Naturgeschichte für alle Stände [Natural history for all classes], Vol 7 (2) or Thierreich 4 (2). Säugethiere 1. Hoffmann'sche Verlags-Buchhandlung, Stuttgart

Ozgul A, Childs DZ, Oli MK, Armitage KB and others (2010) Coupled dynamics of body mass and population growth in response to environmental change. Nature 466:482-485

Pelikán J, Gaisler J, Rödl P (1979) Naši savci [Our mammals]. Academia, nakladatelstvi československá Akademie Věd, Prag

Petzsch H (1933) Einige Beobachtungen an gefangenen Hamstern (Cricetus cricetus L.) [Some observations in captive hamsters (Cricetus cricetus L.)]. Z Saugetierkd 8: 222-227

Petzsch H (1936) Beiträge zur Biologie, insbesondere Forpflanzungsbiologie des Hamsters [Contributions to the biology, particularly reproductive biology, of the hamster]. In: Monographien der Wildsäugetiere [Monographs of wild mammals] 1, Book 12. Deutsche Gesellschaft für Kleintierkunde und Pelztierkunde, Leipzig, p 9-83

Petzsch H (1952) Der Hamster [The hamster], Vol 21. Akademische Verlagsgesellschaft Geest \& Portig KG, Leipzig

Pfeffer A (1954) Lesnická zoologie III. [Forest zoology III.]. Státni zemědělské nakladatelstvī, Prague

Polushina NA, Grenyuk PV, Pankov RA (1988) Gryzuny urbanizirovannyh territorij na primere L'vova [Rodentia of urbanized areas (as exemplified by L'vov)]. In: Abstract of VII All-Union Conference 'Gryzuny', Sverdlovsk p 38-39

Polyakov IY (1968) Vredniye Gryzuny i Bor'ba s Nimi [Harmful rodents and the struggle against them]. Kolos, Leningrad

Popov VA (1960) Mlekopitayushchie Volzhsko-Kamskogo kraya. Nasekomoyadnye, rukokrylye, gryzuny [Mammals of the Volga-Kama area. Insectivora, Chiroptera, Rodentia], Vol 1. Filial AN SSSR, Kazań

Prisny N (ed) (2004) Krasnaya kniga Belgorodskoy oblasti. Redkie i ischezayshchie rasteniya, griby, lichayniki i zhivotnye. Oficialnoe izdanie [Red book of the Belgorod region. Rare and endangered plants, fungi, lichens and animals. Official issue of Belgorod government, Belgorod

Prokopov KP (2008) Biotopicheskoye raspredelenie i chislennost fauny mlekopitauhchikh yuzhnogo Altaya [Biotope distribution and abundance of the mammalian fauna of South Altay]. http://e-lib.gasu.ru/konf/biodiversity/ 2008/1/43.pdf (accessed on 1 October 2015)

Pucek Z (1981) Keys to vertebrates of Poland. Mammals. PWN-Polish Scientific Publishers, Warsaw

Ralph MR, Menaker M (1988) A mutation of the circadian system in golden hamsters. Science 241:1225-1227

Réale D, McAdam AG, Boutin S, Berteaux D (2003) Genetic and plastic responses of a northern mammal to climate change. Proc R Soc Lond B Biol Sci 270:591-596

Rebel H (1933) Die freilebenden Säugetiere Österreichs - als Prodomus einer heimischen Mammalienfaune [The wild mammals of Austria. A handbook of native mammal fauna]. Österreichischer Bundesverlag, Wien

Reiners TE, Eidenschenk J, Neumann K, Nowak C (2014) Preservation of genetic diversity in a wild and captive population of a rapidly declining mammal, the Common hamster of the French Alsace region. Mamm Biol 79: 240-246

Reznik G, Reznik-Schüller H, Mohr U (1976) Clinical anatomy of the European hamster Cricetus cricetus, L. US Department of Health, Education and Welfare, Public Health Service, National Institutes of Health, Washington, DC

Rode P, Didier R (1946) Atlas des mammifères de France [Atlas of the mammals of France], Vol 6. Éditions N. Boubée \& Cie, Paris

Rusin MY, Banaszek A, Mishta AV (2013) The Common hamster (Cricetus cricetus) in Ukraine: evidence for population decline. Folia Zool (Brno) 62:207-213

Ružić A (1976) Neke osobenosti hibernacije hrčka (Cricetus cricetus L.) i njihov značaj za suzbijanje ove štetočine [Some peculiarities in the hibernation of the hamster (Cricetus cricetus L.) and their importance for the control of that pest]. Zašt Bilja 27:397-417

Ružić A (1977) Ispitivanje dinamike brojnosti hrčka (Cricetus cricetus L.) u Vojvodini [Study of the population dynamics of the Common hamster (Cricetus cricetus L.) in Vojvodina]. Zašt Bilja 38:289-300

Ružić A (1978) Rasprostranjenje i brojnost hrčka (Cricetus cricetus Linnaeus, 1758; Rodentia, Mammalia) u Jugoslaviji [Distribution and frequency of occurrence of hamsters (Cricetus cricetus Linnaeus, 1758; Rodentia, Mammalia) in Yugoslavia]. Biosistematika 4:203-208

Saboureau M, Masson-Pévet M, Canguilhem B, Pévet P (1999) Circannual reproductive rhythm in the European hamster (Cricetus cricetus): demonstration of the existence of an annual phase of sensitivity to short photoperiod. J Pineal Res 26:9-16

Sáenz de Miera C, Monecke S, Bartzen-Sprauer J, LaranChich MP, Pevet P, Hazlerigg DG, Simonneaux V (2014) A circannual clock drives expression of genes central for seasonal reproduction. Curr Biol 24:1500-1506

Saino N, Ambrosini R, Rubolini D, von Hardenberg J and others (2011) Climate warming, ecological mismatch at arrival and population decline in migratory birds. Proc R Soc Lond B Biol Sci 278:835-842

Saint Girons MC (1973) Les mammifères de France et du Benelux (faune marine exceptée) [Mammals of France and the Benelux (excluding marine fauna)]. DOIN, Paris

Samosh VM (1975) Materialy po razmnozheniyu i plodovitosti obyknovennogo homyaka (Cricetus cricetus L.) [Data on the breeding and fertility of the Common hamster (Cricetus cricetus L.)]. Russ J Ecol 5:97-98

Savchenko A (ed) (2014) Krasnaya kniga Respubliki Khakassia (Zhivotnye) [Red Data Book of the Republic of Khakassia. Rare and endangered species of animals]. Siberian Federal University, Krasnoyarsk-Abakan

Sazonova NA, Gashev SN (1999) Fauna i ecologia melkikh mlekopitayushchikh zalezhnykh selskokhozyaistvennykh zemel v Tyumenskoy oblasti [Fauna and ecology of micromammalia in fallow lands in the Tyumen region] In: Strictly protected natural areas of Altay province and adjacent territories, tactics of genetic and biodiversity protection. Altayskogo gosudarstvennogo universiteta, Barnaul, p 119-121 
Schmelzer E, Herzig-Straschil B (2013) Ziesel, Feldhamster und Ährenmaus im Burgenland [European ground squirrel, European hamster and mound-building mouse in Burgenland]. Naturschutzbund Burgenland, Eisenstadt

Seluga K, Stubbe M, Mammen U (1996) Zur Reproduktion des Feldhamsters (Cricetus cricetus L.) und zum Ansiedlungsverhalten der Jungtiere. [Reproduction of the Common hamster (Cricetus cricetus L.) and settlement behaviour of juveniles]. Abh Ber Mus Heineanum 3:129-142

Shlyakhtin GV, Il'in VY, Oparin ML, Belyachenko AV and others (2009) Mlekopitayushchie severa Nijne-Voljskogo regiona [Mammals of the Northern Lower-Volga region], Vol 1. Theriofauna composition. Saratov University Press, Saratov

Sidorov GV, Kassal BY, Goncharova AV, Vakhrushev KV (2011) Teriofauna omskoy oblasti (promyslovie vidy) [Theriofauna of Omsk province: game species of rodents]. Nauka, Amphora, Omsk

Simak SV (1990) Fauna pozvonochnikh urochishcha 'Gryzly' (Talovskaya step') [Fauna of vertebrates of the 'Gryzly' site (Talov steppe)]. In: Zhivotny mir yuzhnogo Urala [Animal world of the South Urals]. Uro AN SSSR, Sverdlovsk, p 92-93

Sládek J, Mošanský A (1985) Cicavce okolo nás [Mammals around us]. SÚKK, Banská Bystrica

Sludsky AA (ed) (1977) Mlekopitayushchie Kazakhstana [Mammals of Kazakhstan] Vol 1, Part 2: Rodents. Nauka, Alma-Ata

Smith A, Xie Y (2008) A guide to the mammals of China. Princeton University Press, Princeton, NJ

Soffel K (1922) Bilderatlas zur Zoologie der Säugetiere Europas [Photo atlas of the zoology of European mammals]. R. Voigtländers Verlag, Leipzig

Sokur IT (1963) Shkidlyvi gryzuny I borotba z nymy [Harmful mammals and the fight with them]. AN URSR, Kiiv

Sorokin AS (2002) Krasnaya kniga Tverskoi oblasti [Red Data Book of the Tver region]. Veche Tveri Antek, Tver

Spears N, Finley CM, Whaling CS, Tuthill CR, Zucker I (1990) Sustained reproductive responses in Djungarian hamsters (Phodopus sungorus) exposed to a single long day. J Reprod Fertil 88:635-643

Spitzenberger F (1998) Verbreitung und Status des Hamsters Cricetus cricetus in Österreich [Distribution and status of the hamster Cricetus cricetus in Austria]. In: Stubbe M, Stubbe A (eds) Ökologie und Schutz des Feldhamsters [Ecology and protection of the European hamster]. Martin-Luther-Universität Halle-Wittenberg, Halle/ Saale, p 111-118

Spitzenberger F (ed) (2001) Die Säugetierfanua Österreichs [Mammalian fauna of Austria], Vol 13. Bundesministerium für Land-und Forstwirtschaft, Umwelt und Wasserwirtschaft, Graz

Stanton JC (2014) Present-day risk assessment would have predicted the extinction of the passenger pigeon (Ectopistes migratorius). Biol Conserv 180:11-20

Starikov VP, Blinova TK, Kochurov NV (1989) Zhivotnyj mir kurganskoj oblasti [Wildlife of the Kurgan region]. Kurganskaya oblastnaya organizaciya soyuza zhurnalistov SSSR, Kurgan

Štěpánek O, Baum J (1939) Jak poznám naše zví ata [How to recognize our animals]. Nákladem Česko-Slovenské grafické unie A.S., Praha

Stroganova AS (1954) Mlekopitayushchie stepnogo i polupustynnogo Zavolzhya [Mammals of the steppe and semidesert regions of the Zavolzhye Region]. Tr ZIN Akad Nauk SSSR 16:30-116

Stubbe M, Stubbe A (1998) Der Feldhamster (Cricetus cricetus L.) als Beute von Mensch und Tier sowie seine Bedeutung für das Ökosystem [The European hamster (Cricetus cricetus L.) as prey of humans and animals as well as its importance to the ecosystem]. In: Stubbe M, Stubbe A (eds) Ökologie und Schutz des Feldhamsters [Ecology and protection of the European hamster]. Martin-Luther-Universität Halle-Wittenberg, Halle/Saale, p 81-86

Sulzer FG (1774) Versuch einer Naturgeschichte des Hamsters [An attempt at a natural history of the hamster]. Verlag Naturkunde, Hannover and Berlin-Zehlendorf

Surdacki S (1971) Obszar występowania chomika europejskiego Cricetus cricetus (Linnaeus, 1758) w Polsce. [The distribution and range of the European hamster Cricetus cricetus (Linnaeus, 1758) in Poland]. Ann UMCS Sect B 26:267-285

Surov AV, Poplavskaya NS, Bogomolov PL, Kropotkina MV, Tovpinetz NN, Katzman EA, Feoktistova NY (2016) Synurbanization of the Common hamster (Cricetus cricetus L., 1758). Russ J Biol Invasions 7:69-76

Sysoev ND (1970) Zhivotny mir Vladimirskoy oblasti. Okhotniche-promyslovye vidy [Wildlife of Vladimir province (game species)]. Verhnevolzhskoye knizhnoe izdatelstvo, Yaroslavl

Szabó A (2013) Parlagi sas (Aquila heliaca Savigny 1809) táplálékállat összetétel vizsgálata [Analysis of the prey composition of the eastern imperial eagle (Aquila heliaca Savigny, 1809)]. PhD dissertation, West Hungarian University, Sopron

Tauscher B, Franceschini C, Millesi E (2003) Reproductive output of female European hamsters in an urban environment. In: Nechay G (ed) Proc 11th meeting of the International Hamster Workgroup, Budapest, p 23-26

Tissier M, Handrich Y, Robin JP, Weitten M, Pévet $P$, Kourkgy C, Habold C (2016) How maize monoculture and increasing winter rainfall have brought the hibernating European hamster to the verge of extinction. Sci Rep 6:25531

Tkadlec E, Heroldova M, Víšková V, Bednà M, Zejda J (2012) Distribution of the Common hamster in the Czech Republic after 2000: retreating to optimum lowland habitats. Folia Zool (Brno) 61:246-253

Tovpinetz NN, Evstafiev IL, Karaseva EV (2006) Sklonnost k sinantropii u obyknovennogo khomyaka (Cricetus cricetus) na osnove issledovaniy $\mathrm{v}$ Krymu [Tendency to synanthropy in the Common hamster (Cricetus cricetus) based on investigations in the Crimea]. In: Fauna in anthropogenic environments. Zagorodnyuk I (ed) Pryvatna drukarnya Romana Povcha, Uzhhorod, p 136-145

Traue H (1970) Zur Ernährung des Rotmilans (Milvus milvus L.) während der Brut- und Fütterungsperiode im Verlaufe der Jahre 1962-1967 [On the diet of the red kite (Milvus milvus L.) during the breeding and feeding period of the years 1962-1967]. Naturschutz und naturkundliche Heimatforschung in den Bezirken Halle und Magdeburg 7:38-57

Trouessart EL (1884) Histoire naturelle de la France: Mammifères [Natural history of France: Mammals], Vol 2. Deyrolle, Paris

Turček F (1950) Hlodavce v pôdohospodárstve [Rodents in agriculture]. Orac, Bratislava

Varlygina TI, Zubakin VA, Sobolev NA (eds) (2008) Kras- 
naya kniga Moskovskoy oblasti [Red Book of the Moscow region], $2^{\text {nd }}$ edn (revised and supplemented). Ministry of Ecology and Nature Management of the Moscow Region. The commission on rare and endangered species of animals, plants and fungi, Moscow region. Association of scientific publications-KMK, Moscow

Vieth E (1989) Fitting piecewise linear regression functions to biological responses. J Appl Physiol 67:390-396

Villemey A, Besnard A, Grandadam J, Eidenschenck J (2013) Testing restocking methods for an endangered species: effects of predator exclusion and vegetation cover on Common hamster (Cricetus cricetus) survival and reproduction. Biol Conserv 158:147-154

Vinogradov BS, Gromov IM (1952) Gryzuny fauny SSSR [Rodent fauna of the USSR]. Publishing house of the USSR Academy of Science, Moskva and Leningrad

Vohralík V (1974) Biology of the reproduction of the Common hamster, Cricetus cricetus (L.). Vestn Cesk Spol Zool 38:228-240

Voronin LV (ed) (2004) Krasnaya kniga Yaroslavskoi oblasti [Red Data Book of the Yaroslavl region]. Aleksandr Rutman, Yaroslavl

Voronov GA (1982) Antropogennay dinamika fauny i naseleniya melkikh mlekopitaushchikh yujnoy taigi Kamskogo Priuralya. Anthropogenic dynamics of the small mammal fauna and population in the Southern taiga in the region of Kama (Pre-Urals). In: Neronov V (ed) Contemporary problems of biogeography. VINITI, Moscow, p 103-118

Voronov GA (1993) Biogeografiya melkikh mlekopitayushchikh yuzhnoy taigi Preduralya, Sredney Sibiri I Dalnego Vostoka [The biogeography of small mammals in the southern taiga of the Cis-Urals, Middle Siberia and Far East (anthropogenic dynamics of the fauna and population]. Perm University Press, Perm

Vorontsov NN (1982) Fauna SSSR. Nizshie homyakoobraznye mirovoj fauny morfologiya i ehkologiya [Cricetidae of the world fauna. Part I: morphology and ecology] Fauna SSSR 3. Nauka, Leningrad, p

Vyshegorodskih NV (2015) Pozvonochnye jivotnie kovylnykh mestoobitanii v Orlovskoy oblasti [Vertebrates of Stipa habitats in the Orel region]. In: Zolotukhin NI, Ryzhkov OV, Smelyanski IE (eds) Kovyli i kovylnye stepi Belgorodskoy, Kurskoy, Orlovskoy oblastey: kadastr svedenii, voprosy ohrany [Stipa and Stipa steppes in the Belgorod, Kursk and Orlov regions: data cadastre, protection]. Tsentralnochernozemnogo gosudarstvennogo zapovednika, Kursk, p 88-95

Walz R (2011) Kooperativer Feldhamsterschutz in Sachsen: das Projekt (Ansatz, Anliegen, Inhalte, Finanzierung, Öffentlichkeitsarbeit) [Cooperative hamster protection in Saxony: the project (approach, request, content, funding, publicity). In: Dauderstädt U (ed) Proc Feldhamster in Sachsen. NABU-Landesverband Sachsen, Leipzig, p 9-16

Waßmer T, Wollnik F (1997) Timing of torpor bouts during hibernation in European hamsters (Cricetus cricetus L.). J Comp Physiol B Biochem Syst Environ Physiol 167: 270-279

Weber W, Stubbe M (1984) Zur Reproduktionsbiologie des Hamsters - Cricetus cricetus Linné, 1758 - in der DDR [On the biology of reproduction in hamsters - Cricetus cricetus Linné, 1758-in the GDR]. Säugetierkd Inf 2: 157-166

Weidling A, Stubbe M (1998) Zur aktuellen Verbreitung des Feldhamsters (Cricetus cricetus L.) in Deutschland. [On the current distribution of the Common hamster (Cricetus cricetus L.) in Germany]. In: Stubbe M, Stubbe A (eds) Ökologie und Schutz des Feldhamsters [Ecology and protection of the European hamster]. Martin-Luther-Universität Halle-Wittenberg, Halle/Saale, p 183-186

Weinhold U (1998) Zur Verbreitung und Ökologie des Feldhamsters (Cricetus cricetus L.1758) in Baden Württemberg, unter besonderer Berücksichtigung der räumlichen Organisation auf intensiv genutzten landwirtschaftlichen Flächen im Raum Mannheim-Heidelberg [On the distribution and ecology of the European hamster (Cricetus cricetus L.1758) in Baden-Württemberg, under special consideration of the spatial organisation on intensely used agricultural areas in the region of MannheimHeidelberg]. PhD thesis, Ruprecht-Karls-Universität Heidelberg

Weinhold U (2008) Draft European Action Plan for the conservation of the Common hamster (Cricetus cricetus, L. 1758). In: Book T-PVS/Inf (2008) 9. Convention on the conservation of European wildlife and natural habitatsStanding Committee, Strasbourg

Weinhold U (2011) Die Wiederansiedlung von Feldhamstern in Baden-Württemberg-Anforderungen, Ergebnisse und Erfahrungen [The resettlement of European hamsters in Baden-Württemberg - requirements, results and experiences]. In: Dauderstädt U (ed) Proc Feldhamster in Sachsen. NABU-Landesverband Sachsen e. V., Leipzig, p 9-16

Weinhold U, Kayser A (2006) Der Feldhamster [The European hamster], Vol 625. Westarp WissenschaftenVerlagsgesellschaft mbH, Hohenwarsleben

Wendt W (1989) Zum Aktivitätsverhalten des Feldhamsters, Cricetus cricetus L., im Freigehege [On the activity behaviour of European hamsters, Cricetus cricetus L., in outdoor enclosures]. Säugetierkd Inf 3:3-12

Wenisch M, Godman O (2011) Zum Höchstalter des Feldhamsters [On the maximum age of the Common hamster (Cricetus cricetus)]. Säugetierkd Inf 8:147-148

Yudin BS, Galkina LI, Potapkina NV (1979) Mlekopitayushchie Altae-Sayanskoj Gornoj strany [Mammals of the Altai-Sayan mountain region]. Nauka, Novosibirsk

Zimmermann K (1959) Taschenbuch unserer wildlebenden Säugetiere [Pocket guide to our wild mammals]. Urania, Leibzig and Jena

Zimmermann W (2008) Der Melanismus beim Feldhamster Cricetus cricetus (Linnaeus, 1758), in Thüringen [Melanism in the European hamster Cricetus cricetus (Linnaeus, 1758) in Thuringia]. Landschaftspflege Naturschutz Thüringen 45:89-99

Ziomek J, Banaszek A (2007) The Common hamster, Cricetus cricetus in Poland: status and current range. Folia Zool (Brno) 56:235-242

Zlobin BD, Plesski PB, Charushina AN, Kopysov VA1978) Fauna i ecologiya mlekopitaushchikh. In: Shernin AI (ed) Mlekopitayushchie Kirovskoy oblasti [Fauna and ecology of mammals. Mammals of Kirov province]. Kirov GPI, Kirov 
Appendix. Literature used to create the figures

\begin{tabular}{|c|c|c|c|}
\hline Source & Figures & Source & Figures \\
\hline Albert (2013) & $6,7 \& 8$ & Hamar et al. (1959) & 6 \\
\hline Amand et al. (2012) & 1 & Hanzák (1970) & $6,7 \& 8$ \\
\hline Ambros et al. (2003) & 1 & Hediger (1944) & 1 \\
\hline Anděra \& Horáček (1982) & $6,7 \& 8$ & Hegyeli et al. (2015) & 1 \\
\hline Andreychev \& Kuznetsov (2012) & $2,3 \& 4$ & Hufnagl et al. (2011) & $6,7 \& 8$ \\
\hline Aubry (1961-1962) & $7 \& 8$ & Husson (1949) & $6,7 \& 8$ \\
\hline Babina (2009-2010) & $2,3 \& 4$ & Ilin et al. (2006) & $2,3 \& 4$ \\
\hline Baldaev (2002) & $2,3 \& 4$ & Isaev \& Dmitriev (2010) & $2,3 \& 4$ \\
\hline Bašenina et al. (1957) & $6,7 \& 8$ & Ivanchev \& Kazakova (2011) & $2,3 \& 4$ \\
\hline Bašenina et al. (1961) & 5 & Jennison (1929) & $7 \& 8$ \\
\hline Bayanov \& Kucherov (1995) & $2,3 \& 4$ & Kapitonov (2009) & $2,3 \& 4$ \\
\hline Berdyugin \& Bolshakov (1998) & $2,3 \& 4$ & Karaseva (1962) & $2,3 \& 4$ \\
\hline Bihari (2003) & 1 & Karaseva et al. (1999) & $2,3 \& 4$ \\
\hline Blasius (1857) & $6,7 \& 8$ & Karpenko (2013) & $2,3 \& 4$ \\
\hline Bobrinskiy et al. (1965) & $6,7 \& 8$ & Kayser \& Stubbe (2002) & $6,7 \& 8$ \\
\hline Bolšhakov (1977) & $6,7 \& 8$ & Kiku et al. (2011) & $1,2,3 \& 4$ \\
\hline (Botnariuc \& Tatole 2005) & 1 & Kirikov (1952) & $2,3,4 \& 5$ \\
\hline Brehm (1914) & $6,7 \& 8$ & Konstantinov (2006) & $2,3 \& 4$ \\
\hline Buffon (1765) & $6,7 \& 8$ & Korbut et al. (2013) & $1,2,3 \& 4$ \\
\hline Bundesamt für Naturschutz (2013) & 1 & Kowalski (1964) & 6 \\
\hline Čanády (2013) & 1 & Kratochvíl (1966) & $6,7 \& 8$ \\
\hline Chebakova (ed) (1996) & $2,3 \& 4$ & Kryshtal (1929) & 5 \\
\hline Demyanchik (2004) & $1,6,7 \& 8$ & Kuilik (1962) & $2,3 \& 4$ \\
\hline Didier \& Mathias (1936) & $7 \& 8$ & Kuiters et al. (2011) & 1 \\
\hline Didier \& Rode (1935) & $6,7 \& 8$ & Kuzmin (2006) & $2,3 \& 4$ \\
\hline Dukelskaja \& Stepanova (1932) & $5,7 \& 8$ & Kuznecov (1952) & $5 \& 6$ \\
\hline Dupond (1932) & $6,7 \& 8$ & Kuznetsov (1975) & $6,7 \& 8$ \\
\hline Enzinger et al. (2010) & 1 & La Haye \& Müskens (2014) & 1 \\
\hline Eóry (1959) & $7 \& 8$ & Laptev (1958) & $2,3 \& 4$ \\
\hline Fedorowicz (1928) & $6,7 \& 8$ & Larina et al. (1968) & $2,3 \& 4$ \\
\hline Feoktistova et al. (2016) & $2,3 \& 4$ & Le Louarn \& Saint Girons (1977) & 6 \\
\hline Feriancová-Masárová \& Hanák (1965) & $6,7 \& 8$ & Lindeman et al. (2005) & $2,3 \& 4$ \\
\hline Flint et al. (1965) & $6,7 \& 8$ & Lovassy (1927) & $6,7 \& 8$ \\
\hline Flint et al. (1970) & 6 & Lozan (1971) & $5,7 \& 8$ \\
\hline Franceschini-Zink \& Millesi (2008b) & $6,7 \& 8$ & Lyapunov (2008) & $2,3 \& 4$ \\
\hline Franceschini \& Millesi (2004) & $6,7 \& 8$ & Manninger (1960) & $6,7 \& 8$ \\
\hline Frechkopf (1958) & $6,7 \& 8$ & Markov (1998) & 1 \\
\hline Gaffrey (1961) & $6,7 \& 8$ & Martin (1910) & $6,7 \& 8$ \\
\hline Gelashvili et al. (1999) & $2,3 \& 4$ & Marvin (1968) & $6,7 \& 8$ \\
\hline Geptner et al. (1950) & 6 & Marvin (1966) & $2,3 \& 4$ \\
\hline Gerber (1951) & $6,7 \& 8$ & Melnikov \& Buslaev (2012) & $2,3 \& 4$ \\
\hline Gershenson (1941) & $7 \& 8$ & Minoransky \& Dobrovolsky (2013) & $2,3 \& 4$ \\
\hline Gershenson (1945a) & $2,3 \& 4$ & Mironov et al. (1965) & $2,3 \& 4$ \\
\hline Gershenson (1945b) & $2,3 \& 4$ & Mishta \& Sitnikova (2005) & $2,3 \& 4$ \\
\hline Gershenson (1945c) & $2,3 \& 4$ & Mohr (1954) & $1,6,7 \& 8$ \\
\hline Gershenson (1945d) & $2,3 \& 4$ & Morozova-Turova (1938) & $2,3 \& 4$ \\
\hline Glas (1961) & $6,7 \& 8$ & Moskvitina \& Sushkova (1988) & $2,3 \& 4$ \\
\hline Glotov (1969) & $2,3 \& 4$ & Munteanu (1998) & 1 \\
\hline Gorbachev (1915) & $2,3 \& 4$ & Müskens et al. (2003) & 1 \\
\hline Górecki (1977b) & $5,6,7 \& 8$ & Muzaev (2013) & $2,3 \& 4$ \\
\hline Grizmek (1969) & $6,7 \& 8$ & Myasnikov (1977) & $2,3 \& 4$ \\
\hline Gromov et al. (1963) & $6,7 \& 8$ & Nechay (2000) & 1 \\
\hline Grulich (1975) & 1 & Nechay et al. (1977) & $1,5 \& 6$ \\
\hline Grulich (1980) & 6 & Negrobov (2011) & $2,3 \& 4$ \\
\hline Grulich (1986) & 5 & Nehring (1901) & 5 \\
\hline Guryleva (1968) & $2,3 \& 4$ & Neronov (1965) & $1,2,3 \& 4$ \\
\hline Gyurkó (1975) & 5 & Neronov \& Prokofieva (1969) & $2,3 \& 4$ \\
\hline Hainard (1949) & $6,7 \& 8$ & Niethammer (1982) & $1 \& 6$ \\
\hline Hamar (1967) & $6,7 \& 8$ & Novikova \& Novikov (2007) & 5 \\
\hline
\end{tabular}


Appendix (continued)

\begin{tabular}{|c|c|c|c|}
\hline Source & Figures & Source & Figures \\
\hline Ognev (1916) & $2,3 \& 4$ & Spitzenberger (1998) & 1 \\
\hline Oken (1838) & $6,7 \& 8$ & Spitzenberger (2001) & 1 \\
\hline Pelikán et al. (1979) & $6,7 \& 8$ & Starikov et al. (1989) & $2,3 \& 4$ \\
\hline Petzsch (1936) & $6,7 \& 8$ & Štěpánek \& Baum (1939) & $7 \& 8$ \\
\hline Petzsch (1952) & 6 & Stroganova (1954) & $5,6,7 \& 8$ \\
\hline Pfeffer (1954) & $6,7 \& 8$ & Sulzer (1774) & $6,7 \& 8$ \\
\hline Polushina et al. (1988) & $2,3 \& 4$ & Surdacki (1971) & 1 \\
\hline Polyakov (1968) & 6 & Surov et al. (2016) & $2,3 \& 4$ \\
\hline Popov (1960) & $2,3 \& 4$ & Sysoev $(1970)$ & $2,3 \& 4$ \\
\hline Prisny (2004) & $2,3 \& 4$ & Tauscher et al. (2003) & $7 \& 8$ \\
\hline Prokopov (2008) & $2,3 \& 4$ & Tkadlec et al. (2012) & 1 \\
\hline Pucek (1981) & 6 & Tovpinetz et al. (2006) & $2,3,4 \& 5$ \\
\hline Rebel (1933) & $7 \& 8$ & Trouessart (1884) & $6,7 \& 8$ \\
\hline Reiners et al. (2014) & 1 & Turček (1950) & $6,7 \& 8$ \\
\hline Rode \& Didier (1946) & $6,7 \& 8$ & Varlygina et al. (2008) & $2,3 \& 4$ \\
\hline Rusin et al. (2013) & $1,2,3 \& 4$ & Vinogradov \& Gromov (1952) & $6,7 \& 8$ \\
\hline Ružić (1978) & 1 & Voronin (2004) & $2,3 \& 4$ \\
\hline Saint Girons (1973) & $6,7 \& 8$ & Voronov (1982) & $2,3 \& 4$ \\
\hline Savchenko (2014) & $2,3 \& 4$ & Voronov (1993) & $2,3 \& 4$ \\
\hline Sazonova \& Gashev (1999) & $2,3 \& 4$ & Vorontsov (1982) & $2,3 \& 4$ \\
\hline Schmelzer \& Herzig-Straschil (2013) & 1 & Vyshegorodskih (2015) & $2,3 \& 4$ \\
\hline Seluga et al. (1996) & 6 & Weber \& Stubbe (1984) & 5 \\
\hline Shlyakhtin et al. (2009) & $2,3 \& 4$ & Weidling \& Stubbe (1998) & 1 \\
\hline Sidorov et al. (2011) & $2,3 \& 4$ & Weinhold (1998) & $6,7 \& 8$ \\
\hline Simak (1990) & $2,3 \& 4$ & Weinhold (2008) & 1 \\
\hline Sládek \& Mošanský (1985) & $6,7 \& 8$ & Yudin et al. (1979) & $2,3 \& 4$ \\
\hline Sludsky (1977) & 5 & Zimmermann (1959) & $6,7 \& 8$ \\
\hline Soffel (1922) & $6,7 \& 8$ & Ziomek \& Banaszek (2007) & 1 \\
\hline Sokur (1963) & 6 & Zlobin \& Plesski (1978) & $2,3 \& 4$ \\
\hline Sorokin (2002) & $2,3 \& 4$ & & \\
\hline
\end{tabular}

Editorial responsibility: Nils Bunnefeld, Stirling, UK
Submitted: January 29, 2016; Accepted: July 19, 2016 Proofs received from author(s): September 22, 2016 